\title{
Environmental, Biochemical, and Genetic Drivers of DMSP Degradation and DMS Production in the Sargasso Sea
}

\author{
Naomi Marcil Levine ${ }^{1}$ \\ Vanessa A. Varaljay ${ }^{2}$ \\ Dierdre A. Toole ${ }^{3}$ \\ John W.H. Dacey ${ }^{4}$ \\ Scott C. Doney ${ }^{3}$ \\ Mary Ann Moran ${ }^{5}$
}

\author{
${ }^{1}$ MIT-WHOI Joint Program, Woods Hole, MA 02543 \\ now at: OEB Department, Harvard University, Cambridge MA 02138 \\ ${ }^{2}$ Department of Microbiology, University of Georgia, Athens GA 30602 \\ ${ }^{3}$ Marine Chemistry and Geochemistry, Woods Hole Oceanographic Institution, Woods Hole, \\ MA 02543 \\ ${ }^{4}$ Biology, Woods Hole Oceanographic Institution, Woods Hole, MA 02543 \\ ${ }^{5}$ Department of Marine Sciences, University of Georgia, Athens GA 30602 \\ Running head: Drivers of DMSP degradation and DMS production \\ Corresponding author: \\ Naomi Marcil Levine, \\ nlevine@oeb.harvard.edu \\ OEB Department, Harvard University, Cambridge MA 02138
}

This is the pre-peer reviewed version of the following article:

Levine, N. M., Varaljay, V. A., Toole, D. A., Dacey, J. W. H., Doney, S. C. and Moran, M. A. (2012), Environmental, biochemical and genetic drivers of DMSP degradation and DMS production in the Sargasso Sea. Environmental Microbiology. doi: 10.1111/j.14622920.2012.02700.x

which has been published in final form at http://onlinelibrary.wiley.com/doi/10.1111/j.14622920.2012.02700.x/abstract 


\section{Summary}

2 Dimethylsulfide (DMS) is a climatically relevant trace gas produced and cycled by the

3 surface ocean food web. Mechanisms driving intraannual variability in DMS production and

4 dimethylsulfoniopropionate (DMSP) degradation in open-ocean, oligotrophic regions were

5 investigated during a 10 month time-series at the Bermuda Atlantic Time-series Study site in the

6 Sargasso Sea. Abundance and transcription of bacterial DMSP degradation genes, DMSP lyase

7 enzyme activity, and DMS and DMSP concentrations, consumption rates, and production rates

8 were quantified over time and depth. This interdisciplinary dataset was used to test current

9 hypotheses of the role of light and carbon supply in regulating upper-ocean sulfur cycling.

10 Findings supported UV-A dependent phytoplankton DMS production. Bacterial DMSP-

11 degraders may also contribute significantly to DMS production when temperatures are elevated

12 and UV-A dose is moderate, but may favor DMSP demethylation under low UV-A doses. Three

13 groups of bacterial DMSP degraders with distinct intraannual variability were identified and

14 niche differentiation was indicated. The combination of genetic and biochemical data suggest a

15 modified 'bacterial switch' hypothesis where the prevalence of different bacterial DMSP

16 degradation pathways is regulated by a complex set of factors including carbon supply,

17 temperature, and UV-A dose. 
INTRODUCTION

Dimethylsulfide (DMS) is produced and cycled in marine ecosystems by the surface

22 ocean food web and is the predominant source of natural sulfur to the atmosphere. Once

23 ventilated to the atmosphere, DMS is oxidized to sulfate and methane sulfonate aerosols (Shaw,

24 1983), which act as cloud condensation nuclei. Perturbations in DMS ventilation rates have the

25 potential to alter aerosol abundance, cloud coverage, and cloud properties, which in turn affect

26 the atmospheric radiative balance and Earth's climate (Charlson et al., 1987). Changes in marine

27 physical and chemical properties, such as those projected to occur under high atmospheric $\mathrm{CO}_{2}$

28 conditions, have the potential to affect DMS production by altering community composition,

29 rates of primary production, and heterotrophic microbial activity. An improved understanding of

30 the mechanisms driving DMS production is needed before accurate predictions of the response

31 of the marine sulfur cycle to anthropogenically induced changes can be made.

The primary precursor of DMS, dimethylsulfoniopropionate (DMSP), is produced in

33 surface waters by marine phytoplankton. While phytoplankton directly convert some DMSP to

34 DMS, the majority of the intracellular DMSP pool (particulate DMSP, DMSPp) is released as

35 DMSP into the water column (Simó et al., 2002). This dissolved pool of DMSP (DMSPd) is then

36 rapidly cycled by marine bacterioplankton that degrade DMSP via two competing, enzymatically

37 mediated, pathways (Cantoni and Anderson, 1956; Taylor and Gilchrist, 1991; Kiene et al.,

38 2000). The DMSP demethylation pathway provides bacteria with both carbon and reduced sulfur

39 compounds that are easily incorporated into amino acids and cellular biomass (Kiene, 1996;

40 Kiene and Linn, 2000; Kiene et al., 2000). The DMSP cleavage pathway yields an easily

41 accessible 3-carbon compound (acrylate or 3-hydroxy propionate) and the volatile DMS

42 molecule. Phytoplankton and bacterial DMSP cleavage are the only known pathways that result 
43 in the release of DMS into the water column. Due to bacterial DMSP demethylation and DMS

44 consumption processes, only a small percentage (1-2\%) of DMSP produced by marine

45 phytoplankton is ventilated to the atmosphere as DMS (Bates et al., 1994; Kwint and Kramer,

46 1996). Therefore, understanding the conditions under which DMSP cleavage is favorable relative

47 to demethylation is essential for quantifying current DMS emissions and predicting future 48 emissions.

49 Light has been hypothesized to play an important role in upper ocean sulfur cycling

50 (Toole and Siegel, 2004; Vallina and Simó, 2007). Previous work suggests that phytoplankton

51 cleave DMSP to DMS as an anti-oxidant response to UV radiation (Sunda et al., 2002) and that

52 UV radiation inhibits bacterial DMSPd and DMS consumption rates (Slezak et al., 2007). On the

53 other hand, Kiene et al. (2000) and Simó (2001) hypothesize that the regulation between the two

54 competing bacterial transformations of DMSP (the 'bacterial switch') is driven by bacterial

55 carbon and sulfur demands and by DMSP availability. These authors postulate that the

56 demethylation pathway will be favorable when DMSPd supply is low relative to bacterial carbon

57 and sulfur demands, and cleavage will be favored under low bacterial sulfur demand and 58 elevated DMSPd supply.

59 The ability to demethylate DMSP is widespread in the marine bacterioplankton 60 community. Homologs of the gene responsible for the demethylation of DMSP $(d m d A)$ are 61 harbored by up to $58 \%$ of bacterioplankton cells sampled in the Global Ocean Sampling (GOS) 62 metagenome and at least $80 \%$ of Roseobacter cells and $40 \%$ of SAR11 cells sampled in the 63 Sargasso Sea metagenome (Howard et al., 2006; Howard et al., 2008). These metagenomic 64 analyses support Micro-FISH studies and enrichment experiments that show SAR11 and 65 Roseobacter clades as major players in DMSP cycling in the Sargasso Sea (Ledyard et al., 1993; 
Malmstrom et al., 2004b; Malmstrom et al., 2004a). The $d m d A$ gene can be grouped into 5

67 protein clades and further into 14 subclades based on nucleotide diversity (Howard et al., 2008;

68 Varaljay et al., 2010). In this study, we focus on the three most abundant $d m d A$ clades in the

69 Sargasso Sea: clades A (Roseobacter), C (SAR11), and D (SAR11). Several bacterial DMS-

70 producing genes have also recently been identified; $d d d D$, $d d d L, d d d P, d d d Q, d d d W$, and $d d d Y$

71 (Todd et al., 2007; Curson et al., 2008; Todd et al., 2009; Curson et al., 2011; Todd et al., 2011;

72 Todd et al., 2012). We focus on $d d d P$ (Roseobacter) as metagenomic data and preliminary

73 studies indicate that this gene, along with $d d d Q$, is an order of magnitude more abundant than

$74 d d d D, d d d L, d d d W$ and $d d d Y$ in the Sargasso Sea (Todd et al., 2009; this study).

We investigate intraannual variability and the role of light and carbon availability on microbial and phytoplankton DMS and DMSP (DMS(P)) cycling in an open-ocean, low nutrient,

77 oligotrophic region. During a 10 month study at the Bermuda Atlantic Time-series Study (BATS) station, we quantified the abundance and transcription of key genes involved in the competing DMSP degradation pathways $(d m d A, d d d P)$ and the potential activity of the enzymes involved in bacterial and phytoplankton DMS production. This interdisciplinary dataset provides

81 insight into the activity, diversity, and variability of key genomic groups responsible for organic 82 sulfur cycling that would not be possible with chemical or biological measurements alone.

\section{RESULTS}

\section{Seasonality in DMS(P) concentrations}

A strong seasonal DMS(P) cycle is observed at BATS. Upper ocean $(<80 \mathrm{~m})$ DMSPp

87 concentrations typically peak in the spring concurrent with the shoaling of the mixed layer and 
89 (Fig. 1) peak several months after DMSPp concentrations (Dacey et al., 1998; this study). In

90 2008, upper ocean DMSPd consumption rates were highest during the summer and early fall and

91 were positively correlated both with DMSPd concentrations $\left(\mathrm{r}^{2}=0.54, \mathrm{p}<0.01\right)$ (Fig. 2e) and with

92 mixed layer DMSPd loss rate constants $\left(\mathrm{r}^{2}=0.35, \mathrm{p}<0.01\right)$. DMS consumption was elevated in

93 the mixed layer throughout the year and in the subsurface $(20-60 \mathrm{~m})$ in the early summer (Fig.

94 2f).

The typical seasonal cycle was perturbed in 2008 by a series of events that provided an

96 opportunity to test hypotheses about mechanisms driving upper-ocean sulfur cycling. In May,

97 BATS was under the influence of a mature or decaying cyclonic eddy (D. McGillicuddy,

98 personal comm.). The presence of this upwelling eddy coincided with elevated subsurface

99 DMSP concentrations and DMS(P) consumption rates (Fig. 2b,c,e,f). The BATS site was also

100 heavily influenced by Hurricane Bertha for 4 days immediately preceding the July cruise.

101 Surface waters rapidly restratified, but the remnant of the deep mixing event was still evident

102 during the July sampling, including lower DMS(P) concentrations relative to typical mid-

103 summer values (Fig. $1 \& 2 b, c)$. Increased vertical mixing, increased ventilation of DMS to the

104 atmosphere, and low UV radiative dose from greater convection and cloud cover may have

105 directly or indirectly (through phytoplankton DMSPp production) affected DMS(P) cycling in

106 July.

107

108 Abundance of Bacterial DMSP Degradation Genes

109 Variability in the abundance of the DMSP demethylation gene ( $d m d A$ subclades $\mathrm{A} / 1$, $110 \mathrm{~A} / 2, \mathrm{C} / 2, \mathrm{D} / 1$, and $\mathrm{D} / 3)$ and the DMSP cleavage gene (dddP) over the 10 month time-series was 111 quantified using the quantitative polymerase chain reaction (qPCR) (Fig. 3). The abundance and 
112 seasonal variations of $d m d A$ and $d d d P$ in 2008 were consistent with that of the heterotrophic

113 microbial community that has been described previously for this site (e.g. Carlson et al., 2009;

114 Vila-Costa et al., 2010). $d m d A$ subclade D/1 (SAR11) was the most abundant subclade with an 115 average of $4.6 \times 10^{7}$ copies per liter seawater and a maximum of $1.4 \times 10^{8}$ copies per liter (May 60 $116 \mathrm{~m})$. The abundances of the other $d m d A$ subclades quantified during this study were significantly

117 lower than D/1 with average copies per liter seawater ranging from $1.4 \times 10^{5}(\mathrm{~A} / 2$, Roseobacter $)$ 118 to $5.5 \times 10^{6}(\mathrm{C} / 2$, SAR 11$)$. dddP (Roseobacter) was the second most abundant DMSP degradation 119 gene with an average abundance of $1.2 \times 10^{7}$ copies per liter seawater and a maximum of $5.0 \times 10^{7}$ 120 copies per liter (May $60 \mathrm{~m}$ ). We estimate that up to 33\% of sampled bacterioplankton cells 121 contained a copy of $d m d A$ and up to $11 \%$ of cells contained a copy of $d d d P$, based on total 122 bacterial cell counts as per Howard et al. (2008). Significant variability in the total abundance of 123 DMSP degradation genes was observed, with the highest abundances seen during the summer at 124 depth and the lowest abundances seen during the winter and in surface waters.

125 DMSP gene abundance data separated into three groups with distinct intraannual 126 variability (Supplementary material S1): Group I contained $d d d P$ and $d m d A$ subclades A/1 and $127 \mathrm{D} / 3$ which were correlated with an $\mathrm{r}^{2}>0.65(\mathrm{p}<0.01)$; Group II contained $d m d A$ subclades A/2 128 and $\mathrm{D} / 1$ which were correlated with an $\mathrm{r}^{2}=0.63(\mathrm{p}<0.01)$; and Group III contained $d m d A$ 129 subclade $\mathrm{C} / 2$ which was not correlated with $d m d A \mathrm{~A} / 1$ or $d d d P\left(\mathrm{r}^{2}<0.03, \mathrm{p}>0.30\right)$ and was 130 weakly correlated with $d m d A \mathrm{~A} / 2, \mathrm{D} / 1$, and $\mathrm{D} / 3\left(\mathrm{r}^{2}<0.31, \mathrm{p}<0.01\right)$. The distinct temporal and 131 depth patterns exhibited by the three DMSP gene groups suggest that they were responding to 132 different chemical and physical forcings. A strong correlation between $d d d P$ and $d m d A$ subclade 133 A/1 (both Roseobacter) gene copy number was observed $\left(\mathrm{r}^{2}=0.89, \mathrm{p}<0.01\right)$, although the gene 134 stoichiometry ( $d d d P: \mathrm{A} / 1)$ was $\sim 30: 1 . d m d A$ subclade $\mathrm{C} / 2$, believed to be harbored by SAR11 
135 bacteria, was spatially and temporally distinct from $d m d A$ clades $\mathrm{D} / 1$ (also SAR11) and A/1

136 (Roseobacter). The seasonal succession of $\mathrm{C} / 2$, with peak abundance occurring 5-6 months after

137 the winter mixing event, coincides with seasonal variations observed at BATS for the SAR11

138 subclade Ia (Carlson et al., 2009).

\section{Transcription of Bacterial DMSP Degradation Genes}

Over the 10 month sampling period, DMSP degradation genes $(d d d P$ and $d m d A$

142 subclades $\mathrm{A} / 1, \mathrm{D} / 1$, and $\mathrm{D} / 3$ ) all showed similar low levels of transcription, with less than 1

143 transcript per 1000 gene copies based on qPCR estimates. $d m d A \mathrm{D} / 1$ had the highest measured

144 transcription with a maximum of $3.8 \times 10^{4}$ copies per liter seawater (Oct $60 \mathrm{~m}$ ) and an average of

1451 transcript per 5000 copies. This low level of transcription is consistent with previous

146 metatranscriptomic data from the Sargasso Sea, Sapelo Island, and North Pacific Subtropical

147 Gyre and with qPCR studies in the North Pacific Subtropical Gyre and Monterey Bay (Vila-

148 Costa et al., 2010; Gifford et al., 2011; Varaljay et al., submitted; Varaljay et al. unpublished

149 data). Significant temporal and depth variations in gene transcription were nonetheless detected.

150 The highest transcript numbers for both $d m d A$ and $d d d P$ were observed at $40-60 \mathrm{~m}$

151 during the summer and early fall, and throughout the water column in February 2008 (Fig. 4).

152 With few exceptions (most notably February), all samples with significant DMSP gene

153 transcription also showed elevated rates of DMSPd consumption (Fig. 2e \& 4), where 'elevated'

154 is defined as $>1 \sigma$ above the mean. However, $41 \%$ of samples without significant DMSP gene

155 transcription levels nonetheless had elevated DMSPd consumption rates, specifically surface

156 waters throughout the summer, and upper water column $(<40 \mathrm{~m})$ samples in May, August and

157 September. Due to practical limitations of nucleic acid quantities, the transcription analysis 
158 focused on $d d d P$ and three $d m d A$ subclades $(\mathrm{A} / 1, \mathrm{D} / 1$, and $\mathrm{D} / 3)$ chosen based on metagenomic 159 data, preliminary studies, and a significant positive correlation between measured abundance and 160 DMSPd consumption rates $(\mathrm{p}<0.02)$. However, a different $d m d A$ subclade or DMSP cleavage 161 gene that was not targeted in qPCR (e.g. $d m d A$ subclades $\mathrm{C} / 2, \mathrm{~A} / 2, \mathrm{~B} / 3$, or $\mathrm{E} / 3$ or cleavage genes $162 d d d D, d d d L, d d d Q, d d d Y$ and $d d d W$ ) may have been responsible for the DMSPd consumption in 163 water masses without detectable $d m d A \mathrm{~A} / 1, \mathrm{D} / 1, \mathrm{D} / 3$, or $d d d P$ transcription. In February, 164 elevated $d m d A$ transcription at most depths and for most subclades (Fig. 4) suggested that the 165 bacterial community was actively consuming DMSP, yet the DMSPd consumption rate was not 166 significantly elevated. The driving mechanisms behind higher $d m d A$ transcription in this month 167 are unclear.

168 Transcription of $d m d A$ subclade $\mathrm{D} / 1$, the subclade with the highest gene copy and 169 transcript numbers, was significantly negatively correlated with UV-A dose (Table 1). In 170 addition, all significant $\mathrm{D} / 1$ transcription with the exception of the October $40 \mathrm{~m}$ sample 171 occurred at a UV-A dose less than $20 \%$ of the average summer surface incident UV-A (Table 1). 172 Here we focus on UV-A dose as this wavelength correlated best with changes in the sulfur cycle 173 and has been identified by previous studies as an important regulator of DMSP consumption and 174 DMS production (e.g. Slezak et al., 2001; Toole et al., 2003; Slezak et al., 2007). We found a 175 significant positive relationship between $\mathrm{D} / 1$ transcript number and DMSPd concentration and a 176 significant negative relationship between $\mathrm{D} / 1$ transcript number and total organic carbon (TOC) 177 concentration. This suggests that carbon supply, in particular the relative abundance of DMSPd 178 compared to TOC, may play a role in the transcription of the most abundant $d m d A$ subclade. A 179 significant relationship between $\mathrm{D} / 1$ transcript number and bacterial carbon demand or total 180 bacterial cell counts was not observed. Finally, a significant negative relationship between D/1 
181 transcript number and DMS concentration was seen, suggesting that conditions favorable for

182 DMS production may be unfavorable for DMSP demethylation by bacteria that harbor this $d m d A$

183 subclade.

184 DMS production: potential enzyme activity

185 The potential DMSP lyase assay has been used previously as a proxy for the activity of 186 the phytoplankton DMSP lyase pathway and for potential phytoplankton DMS production 187 (Steinke et al., 2002; Harada et al., 2004; Bell et al., 2007). Here we quantified both 188 phytoplankton and bacterial DMSP lyase activity (DLA) to provide insight into DMS production 189 at BATS. These two pools are operationally defined based on size as per convention where the 190 bacterial fraction was $0.2-1.2 \mu \mathrm{m}$ and the phytoplankton fraction was $>1.2 \mu \mathrm{m}$. Therefore, 191 phytoplankton smaller than $1.2 \mu \mathrm{m}$ were included in the bacterial fraction whereas 192 phytoplankton-associated bacteria were included in the phytoplankton fraction. The dominant 193 picophytoplankton, Prochlorococcus and Synechococcus, produce negligible amounts of DMS 194 (Keller et al., 1989) so are not believed to have contributed significantly to the measured 195 bacterial DLA. Here we focus on differences in temporal and spatial patterns in bacterial and 196 phytoplankton DLA over the sampling period as the rates measured for these two groups are not 197 directly comparable. Phytoplankton DLAs were measured on cell extracts and are presented as 198 specific rates whereas bacterial DLAs were measured on whole cells and are presented as 199 absolute rates. In addition, different DMSP cleavage enzymes in phytoplankton versus bacteria 200 may have performed differently in the DLA assay.

201 Phytoplankton DLA was highest in surface waters in the spring, summer, and early fall 202 (Fig. 5a) concurrent with the shoaling of the mixed layer and was positively correlated with UV203 A radiation dose (Table 1). In addition, 88\% of elevated phytoplankton enzyme activity, defined 
204 as $>1 \sigma$ above the mean, occurred under moderate to high light conditions, defined as UV-A dose 205 greater than $20 \%$ of the average summer surface incident UV-A (Table 1). Phytoplankton DLA 206 was also significantly correlated with TOC, DMS concentration, and temperature (Table 1), 207 variables that were also significantly correlated with one another $\left(\mathrm{r}^{2}>0.42, \mathrm{p}<0.01\right)$ and displayed 208 strong seasonality. Only $11 \%(\mathrm{r}=0.33)$ of the variability in phytoplankton DLA could be 209 explained by DMSPp concentrations (Table 1) and there was no significant relationship between 210 phytoplankton DLA and Chlorophyll a (not shown), indicating that DMSPp concentration and 211 Chlorophyll a alone may not be good proxies for phytoplankton DMS production at BATS. 212 Variation in eukaryotic phytoplankton group pigment concentrations, as identified by high213 performance liquid chromatography (HPLC), explained less than $20 \%$ of the observed variations 214 in DMSPp concentrations and phytoplankton DLA rates (Supplemental Material S2). This 215 further suggests that physical (e.g. UV stress) and chemical conditions may be equally or more 216 important than taxonomic identity in determining DMSPp concentrations and phytoplankton 217 DLA rates at BATS.

218 Potential bacterial DMS production, defined as DLA*DMSPd, was highest in the late 219 summer and early fall between $20 \mathrm{~m}$ and $60 \mathrm{~m}$ (Fig. 5b). Bacterial DLA and potential DMS 220 production were significantly correlated with month, temperature and DMS concentration (Table 221 1), suggesting that bacterial DMS production may be a relevant source of DMS at certain times 222 of year. While there was no significant correlation between UV-A dose and bacterial DMS 223 production, $67 \%$ of elevated bacterial DLA and $33 \%$ of elevated potential bacterial DMS 224 production, defined as $>1 \sigma$ above the mean, occurred under moderate to high light conditions 225 (Table 1). This suggests that bacterial DMS production was UV-A tolerant. A significant 226 positive relationship between bacterial DLA and DMSPd concentration and bacterial DLA and 
227 the ratio of DMSPd:TOC was observed (Table 1). However, these variables could only explain

$2288 \%$ and $23 \%$ of the variability in bacterial DLA, respectively, indicating that carbon availability

229 may not be the primary process regulating bacterial DMS production.

230 Six of the eight samples with measurable $d d d P$ transcription had measurable bacterial

231 DMSP lyase activity (Fig. 5b). Several samples, however, showed elevated bacterial DLA yet

232 had no $d d d P$ transcription. This might occur if DMSP cleavage enzymes have long half-lives,

233 such that cells only need to actively transcribe the $d d d P$ gene intermittently. Alternatively, $d d d P$,

234 although most abundant, may not have been the primary bacterial DMSP cleavage gene being

235 expressed at BATS.

236

\section{DISCUSSION}

DMSP degradation gene data were integrated with observations of physical and 239 biogeochemical parameters relevant to the seasonal DMS(P) cycle in the Sargasso Sea using a 240 non-metric multidimensional scaling (MDS) framework. The two gene groups defined initially 241 based on correlation analysis (Fig. S1) also emerged in the MDS analysis (Fig. 6). Group I

$242(d m d A \mathrm{~A} / 1, d m d A \mathrm{D} / 3, d d d P)$ and Group II ( $d m d A \mathrm{~A} / 2, d m d A \mathrm{D} / 1)$ separated along MDS axis 2,

243 which explained $8 \%$ of the total variance and was positively correlated with date $(\mathrm{r}=0.66$, $244 \mathrm{p}<0.01)$, temperature $(\mathrm{r}=0.57, \mathrm{p}<0.01)$, and DMSPd concentrations $(\mathrm{r}=0.50, \mathrm{p}<0.01)$. This is 245 consistent with a higher abundance of cells containing Group I subclades in the winter and spring 246 when temperature and DMSPd concentrations were low, and an increased abundance of Group II 247 subclades in the summer and fall when temperature and DMSPd concentrations were elevated. 248 MDS axis 1 (Fig. 6) accounted for $84 \%$ of the total variance and correlated best with DMS 249 concentration $(r=0.59, \mathrm{p}<0.01)$, bacterial abundance $(\mathrm{r}=-0.49, \mathrm{p}=0.02)$, bacterial carbon demand 
$250 \quad(\mathrm{r}=-0.47 \mathrm{p}<0.01)$ and UV-A dose $(\mathrm{r}=0.38, \mathrm{p}=0.03)$. We hypothesize that this axis represents

251 depth-dependent niche differentiation among bacteria harboring DMSP degradation genes,

252 potentially driven by radiation dose or carbon availability. The two Roseobacter $d m d A$ gene

253 clades (A/1 and $\mathrm{A} / 2)$ are particularly well separated along this MDS axis and indeed show

254 opposite depth distributions that are especially evident during the summer (Fig. 3c,d).

255 To explore potential mechanisms driving DMSP cleavage versus DMSP demethylation, a

256 second MDS analysis was conducted using only measures of activity: $d m d A \mathrm{D} / 1$ transcript

257 numbers, bacterial DLA*DMSPd, and phytoplankton DLA. MDS axis 1, which explained 47\%

258 of the total variance, separated DMSP cleavage (potential phytoplankton and bacterial DMS

259 production) from DMSP demethylation ( $d m d A \mathrm{D} / 1$ transcription). This axis was positively

260 correlated with date $(\mathrm{r}=0.54, \mathrm{p}<0.01)$, TOC $(\mathrm{r}=0.48, \mathrm{p}<0.01)$, UV-A dose $(\mathrm{r}=0.39, \mathrm{p}=0.04)$ and

261 DMS concentration $(\mathrm{r}=0.37, \mathrm{p}=0.02)$. MDS axis 2 , which explained $27 \%$ of the total variance

262 and was best correlated with DMSPd concentration and DMSPd:TOC ( $\mathrm{r}=0.48, \mathrm{p}<0.01$ for both),

263 separated bacterial activity (bacterial DLA and $d m d A \mathrm{D} / 1$ transcription) from phytoplankton

264 activity (phytoplankton DLA). Overall, analyses suggest that elevated potential phytoplankton

265 DMS production occurred under high UV-A conditions, while elevated bacterial DMSP

266 demethylation occurred under low UV-A conditions, and elevated potential bacterial DMS

267 production occurred under intermediate UV-A doses (Fig $7 \&$ Table 1). These findings agree

268 with previous suggestions that phytoplankton DMS production is enhanced by UV-A dose while

269 bacterial DMSPd consumption is inhibited (Slezak et al., 2001; Sunda et al., 2002; Toole et al.,

270 2006; Archer et al., 2010), and extend these hypotheses to suggest that bacterial DMSP cleavage

271 may be UV-A tolerant. 
273 when DMSPd concentrations were low relative to bacterial carbon and sulfur demands (Kiene et

274 al., 2000; Simó, 2001). However, no significant difference was found in DMSPd:bacterial

275 carbon demand, TOC:bacterial carbon demand, or DMSPd:TOC in locations with elevated

276 bacterial DMSP demethylation gene transcription relative to locations with elevated bacterial

277 DMSP cleavage enzyme activity (student t-test, 95\% confidence). Rather, the correlation 278 analysis (Table 1) and MDS analysis (Fig. 7) suggest that both bacterial DMSP degradation 279 pathways occur under elevated DMSPd and DMSPd:TOC concentrations. Findings further 280 suggest that additional factors including light and temperature may play an important role in 281 regulating the 'bacterial switch', based on observations that bacterial DMSP demethylation 282 occurred under low UV-A dose whereas bacterial DMSP cleavage occurred under elevated 283 temperatures and moderate UV-A dose. Previous studies have suggested that phytoplankton 284 cleave DMSP to DMS as an anti-oxidant response to UV radiation (Sunda et al., 2002; Archer et 285 al., 2010). The prevalence of the less energetically favorable bacterial DMSP cleavage pathway 286 in moderate or high light environments may thus be related to reactive oxygen scavenging 287 capabilities of DMS (Sunda et al., 2002), or possibly to the production of additional reactive 288 oxygen species during demethylation pathway reactions (S. Gifford, personal comm.). Many 289 cultured members of the Roseobacter clade have been shown to both demethylate and cleave 290 DMSP (Gonzalez et al., 2000), making production of DMS by this group particularly sensitive to 291 regulation by environmental conditions. Thus our data suggests a relationship between UV-A 292 dose and bacterial DMSP degradation that warrants further investigation.

293 Both phytoplankton and bacterial DLA were significantly positively correlated with DMS 294 concentration (Table 1), indicating that both may be relevant sources of DMS to the water 
295 column, and yet showed distinctly different variability over the 10 month time-series. In the 296 mixed layer, $61 \%$ of the variability in vertically averaged DMS concentrations ( $\mathrm{p}=0.04)$ and $42 \%$ 297 of the temporal and spatial variability of DMS $(\mathrm{p}=0.03)$ could be explained using a simple linear 298 model combining potential DMS production (phytoplankton DLA and bacterial DLA*DMSPd) 299 and DMS consumption (bacterial DMS consumption and UV-A dose, a proxy for photolysis) 300 (Fig. 8). Only 26\% of the variability in mixed layer DMS concentrations could be explained 301 when potential bacterial DMS production was not included $(\mathrm{p}=0.11)$, and in the period from 302 August through October, $85 \%$ of surface DMS variability $(0-20 \mathrm{~m})$ could be explained by 303 potential bacterial DMS production alone $(\mathrm{p}<0.01)$. This suggests bacteria are important 304 contributors to DMS production at BATS, and were particularly so during the late summer and 305 early fall of 2008. Below the mixed layer, DMS concentrations were low (average $1.0 \pm 1.4 \mathrm{nM}$ ) 306 and significantly correlated with bacterial DMS consumption $\left(r^{2}=0.70, p<0.01\right)$. In addition, the 307 DMS loss rate constant $\left(\right.$ day $\left.^{-1}\right)$ below the mixed layer was significantly higher than the rate 308 constant in the mixed layer $(\mathrm{p}<0.01)$. This indicates a tight coupling between production and 309 loss processes in deeper waters that makes it difficult to predict DMS standing stocks.

310 Drivers of marine biogeochemical cycling are extremely complex and act on numerous 311 scales. We anticipated that an interdisciplinary dataset could assist in teasing apart the bacterial 312 contribution to water column DMS(P) dynamics that begin as changes in gene transcription but 313 are manifested as biogeochemical rates. We conclude that a diverse bacterial community is 314 active in cycling organic sulfur in the Sargasso Sea; that in the late summer and fall, bacteria are 315 important contributors to DMS production; that solar radiation, in particular UV-A dose, plays 316 an important regulatory role in upper ocean sulfur cycling by both phytoplankton and bacteria; 317 and that bacterial DMSP demethylation may be UV-A intolerant while bacterial DMS production 
318 may be UV-A tolerant. Continued characterization of these factors through a combination of

319 physical, chemical, and molecular biological observations will improve our understanding of the

320 role of bacteria in DMS(P) cycling in the surface ocean and yield improved predictions of future

321 DMS emissions.

323 EXPERIMENTAL PROCEDURES

\section{Study site and sample collection}

325 The Bermuda Atlantic Time-series Study (BATS) site is located at $31^{\circ} 40^{\prime} \mathrm{N} 64^{\circ} 10^{\prime} \mathrm{W}$.

326 Samples were collected on 10 monthly cruises to BATS between February and November 2008

327 (Supplemental Material S3). Triplicate samples for functional gene analyses were collected at 0

$328 \mathrm{~m}, 20 \mathrm{~m}, 40 \mathrm{~m}$, and $60 \mathrm{~m}$. Duplicate samples for DMS and DMSP (DMS(P)) concentrations,

329 DMS(P) turnover rates, and DMSP lyase potential enzyme activity (DLA) measurements were

330 collected at the above 4 depths plus $10 \mathrm{~m}$ and $100 \mathrm{~m}$. All samples were collected before sunrise,

331 between $5 \mathrm{AM}$ and $7 \mathrm{AM}$ local time, to avoid the influence of diurnal variability (with the

332 exception of September where samples were collected at 3 AM) and processed immediately.

333 Functional gene and DLA samples were collected in $4 \mathrm{~L}$ acid-washed Nalgene ${ }^{\circledR}$ carboys.

334 Functional gene samples were filtered onto $47 \mathrm{~mm}$ diameter $0.2 \mu \mathrm{m}$ pore-size polycarbonate

335 filters under low pressure $(<0.02 \mathrm{~Pa})$. The filters were changed every 30 minutes for DNA

336 samples and every 15 minutes for RNA samples to minimize sample degradation. On average,

$3373.6 \mathrm{~L}$ of seawater per DNA sample and 2.5 L of seawater per RNA sample were collected onto

338 four filters. After each collection, the RNA and DNA filters were immediately flash frozen in 
339 liquid nitrogen. All functional gene samples were kept in liquid nitrogen or $-80^{\circ} \mathrm{C}$ until they were 340 processed.

341 For the phytoplankton DLA assay, $500 \mathrm{ml}$ of whole seawater was collected on autoclaved

$34225 \mathrm{~mm}$ diameter GF/C glass fiber filters (Whatman, pore-size $\sim 1.2 \mu \mathrm{m}$ ) using gentle filtration

$343(<0.02 \mathrm{~Pa})$. For the bacterial DLA assay, samples were gravity filtered through a $47 \mathrm{~mm}$ diameter

$344 \mathrm{GF} / \mathrm{C}$ glass fiber filter (Whatman, pore-size $\sim 1.2 \mu \mathrm{m}$ ) using a gentle flow to minimize

345 phytoplankton cells lysis during filtration. A total of $325-400 \mathrm{ml}$ of GF/C pre-filtered water

346 (volumes were adjusted to maintain a filtration time of $\sim 30$ minutes) was then collected on

347 autoclaved $25 \mathrm{~mm}$ diameter $0.2 \mu \mathrm{m}$ pore-size polycarbonate filters using gentle filtration $(<0.02$

$348 \mathrm{~Pa}$ ). As a result of extensive testing of the sampling protocol on the measured enzyme activity,

349 only changes in phytoplankton DLA greater than $0.20 \mathrm{nmol} \mathrm{L}^{-1} \mathrm{~min}^{-1}$ and bacterial DLA greater

350 than $0.16 \mathrm{nmol} \mathrm{L}^{-1} \mathrm{~min}^{-1}$ were considered robust (Supplementary material S4). This threshold is

351 significantly lower than the variability observed in both phytoplankton and bacterial DLA over

352 the 10 month time-series.

\section{Concentration and rate measurements}

DMS concentrations were determined using a purge and trap method modified from

356 Zemmelink et al. (2006). Briefly, sulfur gases were sparged from a $4 \mathrm{ml}$ water sample with air or

357 nitrogen gas and trapped using a Carbopack-X trap in Sulfinert-treated 1/8" OD stainless steel

358 tubing. The trapped gases were analyzed on a gas chromatograph (GC) using an Alltech AT-

359 Sulfur capillary $0.32 \mathrm{~mm}$ ID column with an OI Corp. pulsed flame photometric detector

360 (PFPD). Total DMSP and DMSPd were quantified following the protocols described in Slezak et

361 al. (2007) and references therein. Particulate DMSP (DMSPp) was calculated as the difference 
362 between total DMSP and DMSPd. Bacterial DMSPd and DMS consumption rates were

363 determined using the ${ }^{35} \mathrm{~S}$ tracer methods of Kiene and Linn (2000). These methods quantify the

364 turnover rates of the DMSPd and DMS pools by measuring the loss of ${ }^{35}$ S-DMSPd and ${ }^{35}$ S-DMS

365 from the dissolved and volatile pools, respectively. ${ }^{35}$ S-DMSPd and ${ }^{35}$ S-DMS were added at non-

366 perturbing tracer levels of less than $0.05 \mathrm{nM}$. In addition, monthly depth profiles of bacterial

367 carbon demand were determined using ${ }^{3} \mathrm{H}$-leucine incorporation following the protocol of Smith

368 and Azam (1992). Leucine incorporation was converted to bacterial carbon demand using

369 conversion factors from Carlson et al. (1996).

370 Ancillary measurements made by BATS scientists and utilized in this study include:

371 temperature $\left({ }^{\circ} \mathrm{C}\right)$, total organic carbon (TOC) $\left(\mathrm{mol} \mathrm{kg}^{-1}\right)$, Turner Chlorophyll a $(\mu \mathrm{g} / \mathrm{kg})$, HPLC-

372 determined pigments (ng $\mathrm{kg}^{-1}$ ) and bacterial cell counts identified by 4',6-diamidino-2-

373 phenylindole (DAPI) staining (cells L ${ }^{-1}$ ) (http://bats.bios.edu download date 2011, Knap et al.,

374 1997; Steinberg et al., 2001). Additional Chlorophyll a measurements were provided by the

375 Bermuda Bio-Optics Project (N. McDonald personal comm., Siegel et al., 2001). The

376 bioavailable fraction of TOC was assumed to equal semi-labile TOC, defined as total TOC

377 minus the mean TOC concentration measured at depths greater than $3000 \mathrm{~m}$ (Carlson et al.,

378 1994). Unless otherwise specified, we refer to the semi-labile TOC fraction simply as TOC.

379 Monthly vertical profiles of spectral downwelling irradiance for 10 wavelengths (324 nm

$380-665 \mathrm{~nm}$ ) were taken using a Satlantic SeaWiFS profiling multi-channel radiometer (SPMR)

381 coupled with a continuously sampling SeaWiFS multi-channel surface reference (SMSR). The

382 data were collected and processed by the University of California, Santa Barbara (UCSB)

383 Bermuda Bio-Optics Project (Siegel et al., 2001). Due to rapid convection in the mixed layer, the

384 light dose experienced by organisms in this region was assumed to be uniform and was estimated 
385 as the depth-weighted average of the observed light doses over the mixed layer (MLD), defined

386 as the minimum depth where the potential density $\left(\sigma_{\circ}\right)$ is greater than the potential density 387 calculated using surface water salinity and surface temperature minus $0.2^{\circ} \mathrm{C}$. In addition, we 388 define moderate to high light environments as those with greater than $20 \%$ of the average 389 summer surface incident UV-A $\left(0.015 \mathrm{~W} \mathrm{~m}^{-2}\right)$.

391 Gene abundance and transcription

DNA samples were extracted using a phenol:chloroform extraction protocol (modified

393 from Giovannoni et al., 1990; R. Parsons, BIOS, personal comm.) and described in detail in 394 Levine (2010). DNA concentrations ranged from $0.1 \mu \mathrm{g}$ per liter seawater filtered to $2.1 \mu \mathrm{g}$ per 395 liter seawater filtered with an average percent deviation between the biological triplicates of $39621 \%$.

RNA samples were extracted using the Qiagen ${ }^{\circledR}$ RNeasy Mini Kit ${ }^{\mathrm{TM}}$ adapted for 398 environmental samples; a complete description is provided in Levine (2010). An initial on399 column digestion using the Qiagen ${ }^{\circledR}$ RNase-free DNase Set ${ }^{\mathrm{TM}}$ and a second digestion using the 400 Ambion ${ }^{\circledR}$ TURBO DNA-free ${ }^{\mathrm{TM}}$ kit were conducted to eliminate DNA contamination. RNA 401 concentrations ranged from $10 \mathrm{ng}$ per liter seawater filtered to $449 \mathrm{ng}$ per liter seawater filtered 402 with an average percent deviation between the biological triplicates of $26 \%$.

403 Abundance and transcription of DMSP degradation genes were quantified using qPCR on 404 a Bio-Rad iCycler iQ ${ }^{\mathrm{TM}}$. Five non-degenerate $d m d A$ primer sets designed to target subclades $\mathrm{A} / 1$, $405 \mathrm{~A} / 2, \mathrm{C} / 2, \mathrm{D} / 1$, and $\mathrm{D} / 3$ (Varaljay et al., 2010) and a degenerate $d d d P$ primer set targeting Group 4061 (dddP_874F :5'- AAYGAAATWGTTGCCTTTGA -3 and dddP_971R: 5'407 GCATDGCRTAAATCATATC-3') designed by E. Howard (personal comm.) were used. $d m d A$ 
408 primer specificity was previously confirmed (Varaljay et al., 2010) and $d d d P$ specificity was 409 confirmed using Sanger sequencing on environmental samples from BATS DNA.

410 The qPCR cycle specifications and primer specific annealing temperatures are given in 411 supplementary material S5. Gene abundance was quantified for all $5 d m d A$ subclades $(\mathrm{A} / 1, \mathrm{~A} / 2$, $412 \mathrm{C} / 2, \mathrm{D} / 1$, and $\mathrm{D} / 3)$ and $d d d P$ using $12.5 \mu$ l Bio-Rad's iQ ${ }^{\mathrm{TM}}$ SYBR ${ }^{\circledR}$ Green $2 \mathrm{X}$ Supermix, 300 $413 \mathrm{nM}$ final primer concentrations, $2.5 \mu \mathrm{l}$ Bovine Serum Albumin (BSA, final concentration $500 \mathrm{ng}$ $414 \mu \mathrm{l}^{-1}$, New England Biolabs), and $3.0 \mu \mathrm{l}$ of template in a $25.0 \mu \mathrm{l}$ final reaction volume. Technical 415 duplicates (same sample) of biological triplicates (same time and depth but processed 416 independently) were analyzed, yielding 6 reactions per sample. Gene transcription was 417 quantified for $d d d P$ and $d m d A$ subclades $\mathrm{A} / 1, \mathrm{D} / 1$, and $\mathrm{D} / 3$ with Bio-Rad's iScript One-Step RT418 PCR with SYBR ${ }^{\circledR}$ Green kit using the same concentrations as above except $5.0 \mu 1$ of template

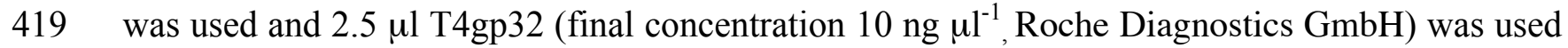
420 in place of BSA. Technical duplicates of biological duplicates $(\mathrm{N}=4)$ and a reverse-transcriptase 421 enzyme control (-RT) were run for each sample with each primer set to confirm the absence of 422 contaminating DNA. The addition of BSA or T4gp32 eliminated PCR inhibition (Supplementary 423 material S6).

Ten-fold serially diluted standard curves covering the sample range were run in duplicate 425 on each plate. Standards were made from PCR products from environmental DNA cloned into 426 the PCR 2.1 or PCR 4.0 vector using the TOPO TA Cloning ${ }^{\circledR}$ kit (Invitrogen) and were 427 quantified based on the length of the amplicon insert and the concentration. Triplicate no428 template controls were run on every plate. A single peak was confirmed from melt curve analysis for all primers, and qPCR 430 products were verified by agarose gel. Samples with transcript numbers greater than one standard 
431 deviation above the mean were marked as "elevated transcription". Some samples analyzed for

432 the transcription of subclade $d m d A \mathrm{~A} / 1$ and $d d d P$ showed non-specific amplification by melt

433 curve analysis, most likely due to low initial gene copy number. Samples with multiple melting

434 curve peaks but with at least one peak at the correct melting temperature (compared to the

435 standard clone melt curve) were marked as non-quantifiable "transcription present". Of the 40

436 samples analyzed for subclade A/1 transcription, 11 samples showed specific amplification, and

43721 were marked as "transcription present". $d d d P$ transcript numbers were too low in all 40

438 samples for a quantitative analysis of copy number; however, 8 samples were marked as

439 "transcription present".

440 The PCR efficiency of the environmental samples was shown to be within error of the

441 efficiency of the standards using the LinRegPCR program (Ramakers et al., 2003; Ruijter et al.,

442 2009). Gene abundance and transcription data are presented as copies $L^{-1}$ of seawater filtered.

443 RNA samples with DNA contamination greater than $3 \%$ of the RNA signal were discarded. Of

444 RNA samples with quantifiable or qualitative transcription, only one sample analyzed (for

445 subclade $\mathrm{D} / 1$ transcription) was discarded due to DNA contamination.

447 DMSP lyase activity

448 The methods of Harada et al. (2004) and Steinke et al. (2000), developed to measure the 449 activity of the phytoplankton DMSP lyase pathway, were applied to two operationally defined 450 fractions: phytoplankton $(>1.2 \mu \mathrm{m})$ and bacterial $(0.2 \mu \mathrm{m}-1.2 \mu \mathrm{m})$. The protocol following 451 filtration (see above) was identical for both size fractions and is described in detail in Levine 452 (2010). Briefly, the filter was placed in a $14 \mathrm{ml}$ amber glass serum vial containing $1 \mathrm{ml}$ of 200 $453 \mathrm{mM}$ Tris buffer ( $\mathrm{pH} 8)$ with $500 \mathrm{mM} \mathrm{NaCl}$. The vial was vortexed and incubated for 20 minutes. 
454 This effectively lyses phytoplankton cells (Steinke et al., 2000) but is not stringent enough to 455 lyse bacterial cells (Supplementary material S7). Following the incubation, a saturating 456 concentration of DMSP was added (final concentration $5 \mathrm{mM}$ ) and the vial was immediately 457 crimped. The evolution of DMS in each vial was analyzed using focused headspace samples on 458 the GC system described above. Five time-points were measured per sample over an 18 minute 459 interval. A short measurement period was chosen to negate the possibility of enzyme induction. 460 This was confirmed by laboratory and field tests that showed a linear increase in DMS 461 concentrations over the first 30 minutes of the DLA assay.

462 Enzyme activity is temperature dependent; therefore, all DLA measurements were made 463 at the MLD temperature using an under-way seawater bath to best approximate in situ 464 conditions. Assay temperatures ranged from $21^{\circ}-26.5^{\circ} \mathrm{C}$ over the 10 month time-series. The 465 difference between the DLA assay temperature and the $100 \mathrm{~m}$ water temperature ranged from $<$ $4661{ }^{\circ} \mathrm{C}$ in February to $6.5^{\circ} \mathrm{C}$ in August and September. The DLA assay most likely overestimates 467 enzyme activity at depth in the summer due to this temperature difference; however, this 468 overestimation is only on the order of $20 \%$ (Supplementary material S4).

469 DMS concentrations were quantified using a standard curve defined by diluting pure 470 DMS in aqueous solutions $(0.5-10 \mu \mathrm{M})$. The DLA rate was calculated as: 
474 where $\frac{d D M S}{d t}$ is the slope of the best-fit trend line to the observed change in DMS with time, $475 \frac{d D M S P_{a b i o t i c}}{d t}$ is the correction for the abiotic degradation of DMSP in the assay (Supplementary 476 material S8), and $\mathrm{Vol}$ is the volume of seawater filtered. The $\mathrm{r}^{2}$ of the $\frac{d D M S}{d t}$ trend line was 477 typically 0.99 or better. The potential DLA for each depth was calculated as the average of the 478 duplicate samples. An additional correction was applied to bacterial DLA samples to account for 479 the effect of the polycarbonate filter on the observed DMS concentrations (Supplementary 480 material S8).

$481 \quad$ Potential enzyme assays measure the non-substrate limited activity of the enzymes that is 482 assumed to be proportional to the enzyme concentration in solution. In order to better estimate 483 rates of bacterial DMS production, the observed bacterial DLA was multiplied by the in situ 484 DMSPd concentration as bacteria are dependent on external sources of DMSP. However, the 485 conclusions of this study remain unchanged if the analyses are conducted using bacterial DLA 486 alone. A similar correction for the phytoplankton DLA activity was not made as the intracellular 487 concentration of DMSPp in DMS-producing cells may not be linearly related to total water 488 column DMSPp concentration due to significant, species-specific, variability in DMSP 489 production and DMSP lyase enzyme concentration (e.g. Keller et al., 1989; Matrai and Keller, 490 1994).

\section{Statistical analysis}

To investigate potential environmental drivers of DMSP degradation and DMS

494 production, linear relationships between a suite of physical, chemical and biological factors and 
495 gene abundance, expression, and DLA were investigated. Specifically, DMS, DMSPp, DMSPd, 496 and TOC concentrations, DMSP:TOC, DMSP consumption, Chlorophyll a, bacterial carbon 497 demand, bacterial abundance, temperature, depth, $340 \mathrm{~nm}$ light dose (UV-A), $490 \mathrm{~nm}$ light dose, 498 and $684 \mathrm{~nm}$ light dose were used. The Results and Discussion sections focus on the 499 environmental variables most significantly correlated with changes in sulfur cycling.

500 A non-metric multidimensional scaling (MDS) analysis was conducted using R's Vegan 501 package (Oksanen et al., 2010) to further investigate potential drivers of DMSP degradation gene 502 abundance. Gene abundance data were log-transformed and normalized as a fraction of the 503 highest value. The Bray-Curtis method was used to calculate dissimilarity indices and 4 504 dimensions were chosen as additional dimensions resulted in minimal increases in the goodness 505 of fit, calculated as Kruskal's Stress (formula I). For each axis of variability, the MDS analysis 506 yielded sample scores for each sample and the projection or weighting of each gene data set on 507 that axis (variable score). The axis sample scores were then linearly regressed against a suite of 508 physical and chemical observations (see above) to investigate potential sources of variation. In 509 addition, the day of the year was used to determine the impact of season on the distribution of 510 bacterial DMSP genes.

511 A second MDS analysis was performed as described above to further investigate potential 512 the mechanisms driving variability in DMSP degradation and DMS production. Here $d m d A \mathrm{D} / 1$ 513 gene transcription, potential bacterial DMS production (DLA*DMSPd), and potential 514 phytoplankton DMS production (DLA) were used. Each data set was normalized to range from 515 zero to one before the analysis was performed. 


\section{ACKNOWLEDGEMENTS:}

517 We would like to acknowledge Aimee Neeley and Erinn Howard for significant

518 contributions to this work, D. Siegel and D. Court for assistance with the solar radiation data, the 519 staff at the Bermuda Institute of Ocean Sciences, and the captain and crew of the $R / V$ Atlantic 520 Explorer. This research was funded by National Science Foundation (NSF) grants OCE521 0525928, OCE-072417, and OCE-042516. Additional funding was provided by the NSF Center 522 for Microbial Oceanography Research and Education (CMORE), the Gordon and Betty Moore 523 Foundation, the Scurlock Fund, the Ocean Ventures Fund, a National Defense Science and 524 Engineering Graduate Fellowship, and an Environmental Protection Agency STAR Graduate 525 Fellowship. 


\section{REFERENCES}

529 Archer, S.D., Ragni, M., Webster, R., Airs, R.L., and Geider, R.J. (2010) Dimethyl 530 sulfoniopropionate and dimethyl sulfide production in response to photoinhibition in Emiliania 531 huxleyi. Limnology and Oceanography 55: 1579-1589. cycling of sulfur in surface seawater of the Northeast Pacific. Journal of Geophysical Research534 Oceans 99: 7835-7843.

535 Bell, T.G., Malin, G., Kim, Y.N., and Steinke, M. (2007) Spatial variability in DMSP-lyase activity along an Atlantic meridional transect. Aquatic Sciences 69: 320-329. polysiphonia lansoa. Journal of Biological Chemistry 222: 171-177. carbon from the euphotic zone in the northwestern Sargasso Sea. Nature 371: 405-408.

Carlson, C.A., Ducklow, H.W., and Sleeter, T.D. (1996) Stocks and dynamics of 542 bacterioplankton in the northwestern Sargasso Sea. Deep-Sea Research Part II-Topical Studies 543 in Oceanography 43: 491-515.

544 Carlson, C.A., Morris, R., Parsons, R., Treusch, A.H., Giovannoni, S.J., and Vergin, K. (2009) 545 Seasonal dynamics of SAR11 populations in the euphotic and mesopelagic zones of the 546 northwestern Sargasso Sea. ISME Journal 3: 283-295.

547 Charlson, R.J., Lovelock, J.E., Andreae, M.O., and Warren, S.G. (1987) Oceanic phytoplankton, 548 atmospheric sulfur, cloud albedo and climate. Nature 326: 655-661.

549 Curson, A.R.J., Sullivan, M.J., Todd, J.D., and Johnston, A.W.B. (2011) DddY, a periplasmic 550 dimethylsulfoniopropionate lyase found in taxonomically diverse species of Proteobacteria. 551 ISME Journal 5: 1191-1200.

552 Curson, A.R.J., Rogers, R., Todd, J.D., Brearley, C.A., and Johnston, A.W.B. (2008) Molecular 553 genetic analysis of a dimethylsulfoniopropionate lyase that liberates the climate-changing gas 554 dimethylsulfide in several marine alpha-proteobacteria and Rhodobacter sphaeroides. 555 Environmental Microbiology 10: 757-767. 
Dacey, J.W.H., Howse, F.A., Michaels, A.F., and Wakeham, S.G. (1998) Temporal variability of dimethylsulfide and dimethylsulfoniopropionate in the Sargasso Sea. Deep-Sea Research Part IOceanographic Research Papers 45: 2085-2104.

Gifford, S.M., Sharma, S., Rinta-Kanto, J.M., and Moran, M.A. (2011) Quantitative analysis of a deeply sequenced marine microbial metatranscriptome. ISME Journal 5: 461-472.

Giovannoni, S.J., Delong, E.F., Schmidt, T.M., and Pace, N.R. (1990) Tangential Flow Filtration and Preliminary Phylogenetic Analysis of Marine Picoplankton. Applied and Environmental Microbiology 56: 2572-2575.

Gonzalez, J.M., Simó, R., Massana, R., Covert, J.S., Casamayor, E.O., Pedrós-Alió, C., and Moran, M.A. (2000) Bacterial community structure associated with a dimethylsulfoniopropionate-producing North Atlantic algal bloom. Applied and Environmental Microbiology 66: 4237-4246.

Harada, H., Rouse, M.A., Sunda, W., and Kiene, R.P. (2004) Latitudinal and vertical distributions of particle-associated dimethylsulfoniopropionate (DMSP) lyase activity in the western North Atlantic Ocean. Canadian Journal of Fisheries and Aquatic Sciences 61: 700-711.

Howard, E.C., Sun, S.L., Biers, E.J., and Moran, M.A. (2008) Abundant and diverse bacteria involved in DMSP degradation in marine surface waters. Environmental Microbiology 10: $2397-$ 2410 .

Howard, E.C., Henriksen, J.R., Buchan, A., Reisch, C.R., Buergmann, H., Welsh, R. et al. (2006) Bacterial taxa that limit sulfur flux from the ocean. Science 314: 649-652.

Keller, M.D., Bellows, W.K., and Guillard, R.R.L. (1989) Dimethylsulfide production in marine phytoplankton. In Biogenic sulfur in the environment. Saltzman, E.S., and Cooper William, W.J. (eds). Washington, D.C.: ACS Symposium Series, American Chemical Society, pp. 167-182.

Kiene, R.P. (1996) Production of methanethiol from dimethylsulfoniopropionate in marine surface waters. Marine Chemistry 54: 69-83.

Kiene, R.P., and Linn, L.J. (2000) The fate of dissolved dimethylsulfoniopropionate (DMSP) in seawater: Tracer studies using S-35-DMSP. Geochimica et Cosmochimica Acta 64: 2797-2810.

Kiene, R.P., Linn, L.J., and Bruton, J.A. (2000) New and important roles for DMSP in marine microbial communities. Journal of Sea Research 43: 209-224.

Knap, A.H., Michaels, A.F., Steinberg, D.K., Bahr, F., Bates, N.R., Bell, S. et al. (1997) Bermuda Atlantic Time-series Study Methods Manual Version 4. 
Kwint, R.L.J., and Kramer, K.J.M. (1996) Annual cycle of the production and fate of DMS and DMSP in a marine coastal system. Marine Ecology-Progress Series 134: 217-224.

589 Ledyard, K.M., Delong, E.F., and Dacey, J.W.H. (1993) Characterization of a DMSP-degrading bacterial isolate from the Sargasso Sea. Archives of Microbiology 160: 312-318.

Levine, N.M. (2010) Understanding the ocean carbon and sulfur cycles in the context of a 592 variable ocean : a study of anthropogenic carbon storage and dimethylsulfide production in the Atlantic Ocean. In Chemical Oceanography. Woods Hole: MIT-WHOI Joint Program, p. 298.

594

595

596

597

598

599

600

601

602

603

604

605

606

607

608

609

610

611

612

613

614

615

616

617

Malmstrom, R.R., Kiene, R.P., and Kirchman, D.L. (2004a) Identification and enumeration of bacteria assimilating dimethylsulfoniopropionate (DMSP) in the North Atlantic and Gulf of Mexico. Limnology and Oceanography 49: 597-606.

Malmstrom, R.R., Kiene, R.P., Cottrell, M.T., and Kirchman, D.L. (2004b) Contribution of SAR11 bacteria to dissolved dimethylsulfoniopropionate and amino acid uptake in the North Atlantic ocean. Applied and Environmental Microbiology 70: 4129-4135.

Matrai, P.A., and Keller, M.D. (1994) Total organic sulfur and dimethylsulfoniopropionate in marine-phytoplankton - intracellular variations. Marine Biology 119: 61-68.

Oksanen, J., Blanchet, F.G., Kindt, R., Legendre, P., O'Hara, R.B., Simpson, G.L. et al. (2010) In: vegan: Community Ecology Package. $\mathrm{R}$ package version 1.17-3. http://CRAN.Rproject.org/package-vegan.

Ramakers, C., Ruijter, J.M., Deprez, R.H.L., and Moorman, A.F.M. (2003) Assumption-free analysis of quantitative real-time polymerase chain reaction (PCR) data. Neuroscience Letters 339: 62-66.

Ruijter, J.M., Ramakers, C., Hoogaars, W.M.H., Karlen, Y., Bakker, O., van den Hoff, M.J.B., and Moorman, A.F.M. (2009) Amplification efficiency: linking baseline and bias in the analysis of quantitative PCR data. Nucleic Acids Research 37: e45.

Shaw, G.E. (1983) Bio-controlled thermostasis involving the sulfur cycle. Climatic Change 5: 297-303.

Siegel, D.A., Westberry, T.K., O'Brien, M.C., Nelson, N.B., Michaels, A.F., Morrison, J.R. et al. (2001) Bio-optical modeling of primary production on regional scales: the Bermuda BioOptics project. Deep-Sea Research Part II-Topical Studies in Oceanography 48: 1865-1896.

Simó, R. (2001) Production of atmospheric sulfur by oceanic plankton: biogeochemical, ecological and evolutionary links. Trends in Ecology \& Evolution 16: 287-294. 
619 Coupled dynamics of dimethylsulfoniopropionate and dimethylsulfide cycling and the microbial

620 food web in surface waters of the North Atlantic. Limnology and Oceanography 47: 53-61.

621 Slezak, D., Brugger, A., and Herndl, G.J. (2001) Impact of solar radiation on the biological 622 removal of dimethylsulfoniopropionate and dimethylsulfide in marine surface waters. Aquatic 623 Microbial Ecology 25: 87-97.

624 Slezak, D., Kiene, R.P., Toole, D.A., Simó, R., and Kieber, D.J. (2007) Effects of solar radiation 625 on the fate of dissolved DMSP and conversion to DMS in seawater. Aquatic Sciences 69: 377626393.

627 Smith, D.C., and Azam, F. (1992) A simple, economical method for measuring bacterial protein 628 synthesis rates in seawater using 3H-leucine. Mar Microb Food Webs 6: 107-114.

629 Steinberg, D.K., Carlson, C.A., Bates, N.R., Johnson, R.J., Michaels, A.F., and Knap, A.H. 630 (2001) Overview of the US JGOFS Bermuda Atlantic Time-series Study (BATS): a decade-scale 631 look at ocean biology and biogeochemistry. Deep-Sea Research Part II-Topical Studies in 632 Oceanography 48: 1405-1447.

633 Steinke, M., Malin, G., Turner, S.M., and Liss, P.S. (2000) Determinations of 634 dimethylsulphoniopropionate (DMSP) lyase activity using headspace analysis of 635 dimethylsulphide (DMS). Journal of Sea Research 43: 233-244.

636 Steinke, M., Malin, G., Gibb, S.W., and Burkill, P.H. (2002) Vertical and temporal variability of 637 DMSP lyase activity in a coccolithophorid bloom in the northern North Sea. Deep-Sea Research 638 Part II-Topical Studies in Oceanography 49: 3001-3016.

639 Sunda, W., Kieber, D.J., Kiene, R.P., and Huntsman, S. (2002) An antioxidant function for 640 DMSP and DMS in marine algae. Nature 418: 317-320.

641 Taylor, B.F., and Gilchrist, D.C. (1991) New routes for aerobic biodegradation of 642 dimethylsulfoniopropionate. Applied and Environmental Microbiology 57: 3581-3584.

643 Todd, J.D., Kirkwood, M., Newton-Payne, S., and Johnston, A.W.B. (2012) DddW, a third 644 DMSP lyase in a model Roseobacter marine bacterium, Ruegeria pomeroyi DSS-3. ISME 645 Journal 6: 223-226.

646 Todd, J.D., Curson, A.R.J., Dupont, C.L., Nicholson, P., and Johnston, A.W.B. (2009) The dddP 647 gene, encoding a novel enzyme that converts dimethylsulfoniopropionate into dimethyl sulfide, 648 is widespread in ocean metagenomes and marine bacteria and also occurs in some Ascomycete 649 fungi. Environmental Microbiology 11: 1376-1385. 

(2011) DddQ, a novel, cupin-containing, dimethylsulfoniopropionate lyase in marine roseobacters and in uncultured marine bacteria. Environmental Microbiology 13: 427-438.

Todd, J.D., Rogers, R., Li, Y.G., Wexler, M., Bond, P.L., Sun, L. et al. (2007) Structural and regulatory genes required to make the gas dimethyl sulfide in bacteria. Science 315: 666-669.

Toole, D.A., and Siegel, D.A. (2004) Light-driven cycling of dimethylsulfide (DMS) in the Sargasso Sea: Closing the loop. Geophysical Research Letters 31.

Toole, D.A., Kieber, D.J., Kiene, R.P., Siegel, D.A., and Nelson, N.B. (2003) Photolysis and the dimethylsulfide (DMS) summer paradox in the Sargasso Sea. Limnology and Oceanography 48 :

$659 \quad 1088-1100$.

Toole, D.A., Slezak, D., Kiene, R.P., Kieber, D.J., and Siegel, D.A. (2006) Effects of solar 661 radiation on dimethylsulfide cycling in the western Atlantic Ocean. Deep-Sea Research Part I662 Oceanographic Research Papers 53: 136-153.

663 Vallina, S.M., and Simó, R. (2007) Strong relationship between DMS and the solar radiation 664 dose over the global surface ocean. Science 315: 506-508.

Varaljay, V., Giffford, S.M., Wilson, S.T., Sharma, S., Karl, D.M., and Moran, M.A. (submitted) The Abundance and Diversity of Bacterial

667 Dimethylsulfoniopropionate-degrading Genes dmdA and dddP in the

668 Oligotropic North Pacific Subtropical Gyre.

669 Varaljay, V.A., Howard, E.C., Sun, S.L., and Moran, M.A. (2010) Deep sequencing of a 670 dimethylsulfoniopropionate-degrading gene (dmdA) by using PCR primer pairs designed on the 671 basis of marine metagenomic data. Applied and Environmental Microbiology 76: 609-617.

672 Vila-Costa, M., Rinta-Kanto, J.M., Sun, S.L., Sharma, S., Poretsky, R., and Moran, M.A. (2010) 673 Transcriptomic analysis of a marine bacterial community enriched with 674 dimethylsulfoniopropionate. ISME Journal 4: 1410-1420.

675 Yoch, D.C., Ansede, J.H., and Rabinowitz, K.S. (1997) Evidence for intracellular and 676 extracellular dimethylsulfoniopropionate (DMSP) lyases and DMSP uptake sites in two species 677 of marine bacteria. Applied and Environmental Microbiology 63: 3182-3188. 279. 


\section{Figure Captions:}

684 Figure 1: Seasonal cycle of vertically averaged mixed layer DMS concentration at BATS. The 685 mean seasonal cycle of mixed layer DMS concentrations averaged over 1992-1994 (Dacey et al., 686 1998) is shown in the solid black line with the $1 \sigma$ variation shown with gray shading. The 687 average mixed layer DMS concentrations for 2008 (this study) is shown as a black dashed line. 688 Note the influence of Hurricane Bertha during July 2008 resulting in atypically low mixed layer 689 DMS concentrations.

691 Figure 2: Variability in the upper ocean sulfur cycle at BATS in 2008. The concentrations of 692 DMS, DMSPp and DMSPd in nM are given in panels a, b and c, respectively. The UV-A light 693 dose $(340 \mathrm{~nm})$ is given in panel $\mathrm{d}$. The rates of DMSPd and DMS consumption in $\mathrm{nM} \mathrm{d}^{-1}$ are 694 plotted in panels e and f, respectively. The thick solid gray lines indicate the mixed layer depth, 695 defined as the minimum depth where the potential density $\left(\sigma_{\theta}\right)$ is greater than the potential 696 density calculated using surface water salinity and surface temperature minus $0.2^{\circ} \mathrm{C}$. The thin 697 solid gray lines represent the $1 \sigma$ variation of the mixed layer depth during the monthly cruise and 698 the dashed gray lines show the deepening of the mixed layer due to Hurricane Bertha.

700 Figure 3: The abundance of DMSP degradation genes at BATS. Panels a-e show the abundance 701 of $d m d A$ subclades $\mathrm{D} / 1, \mathrm{~A} / 2, \mathrm{C} / 2, \mathrm{D} / 3$, and $\mathrm{A} / 1$ in copies $\mathrm{L}^{-1}$ of seawater, respectively. Panel $\mathrm{f}$ 702 plots the abundance of $d d d P$ in copies $\mathrm{L}^{-1}$. The symbol color corresponds to the number of gene 703 copies $\mathrm{L}^{-1}$. The average measurement error is $23 \%$, with a range of $5 \%-70 \%$. Measurements 704 with an error greater than 25\% are indicated with hash marks (e.g. D/1 March 60 m). Note the 705 more than two orders of magnitude variation in color bar scales. The solid gray lines indicate the 
706 mixed layer depth and the dashed gray lines show the deepening of the mixed layer due to 707 Hurricane Bertha.

709 Figure 4: Transcription of DMSP degradation genes at BATS. Transcript number for $d m d A$ 710 subclades $\mathrm{D} / 1, \mathrm{D} / 3$, and $\mathrm{A} / 1$ and $d d d P$ in copies $\mathrm{L}^{-1}$ are plotted in panels a-d, respectively. The

711 symbol color corresponds to the number of transcript copies $\mathrm{L}^{-1}$. The average measurement error 712 is $37 \%$, with a range of $0.5 \%-140 \%$. Measurements with an error greater than $55 \%$ are 713 indicated with hashed marks (e.g. D/1 March $0 \mathrm{~m}$ ). Samples marked as "transcription present" 714 are denoted by + symbols. Black open circles denote samples with no detectable transcription.

715 The solid gray lines indicate the mixed layer depth and the dashed gray lines show the deepening 716 of the mixed layer due to Hurricane Bertha.

718 Figure 5: Phytoplankton and bacterial DMSP lyase potential enzyme activity. Panel a shows the 719 potential phytoplankton DMS production as determined by the phytoplankton DMSP lyase 720 potential enzyme activity. Panel b shows potential bacterial DMS production estimated from 721 bacterial DMSP lyase activity and dissolved DMSPd concentrations. Sample locations for 722 transcription analysis are shown as white dots and the locations with $d d d P$ transcripts present are 723 denoted with black squares. The solid gray lines indicate the mixed layer depth and the dashed 724 gray lines show the deepening of the mixed layer due to Hurricane Bertha.

726 Figure 6: Multi-dimensional scaling plot of Group I and Group II gene abundance. The first and 727 second axis scores for all samples $(\mathrm{N}=40)$ and the variable scores for $d m d A \mathrm{~A} / 1, \mathrm{~A} / 2, \mathrm{D} / 1$, and $728 \mathrm{D} / 3$ and $d d d P$ are displayed. Samples are shaded according to season: winter (Feb - Mar), spring 
729 (Apr - May), summer (June - Sept), and fall (Oct - Nov). July samples are plotted as open black

730 circles and May samples from $40 \mathrm{~m}$ and $60 \mathrm{~m}$ are plotted as open gray triangles. The samples

731 cluster into two groups, Group I with high $\mathrm{A} / 1, \mathrm{D} / 3$, and $d d d P$ copy numbers and Group II with

732 high $\mathrm{A} / 2$ and $\mathrm{D} / 1$ copy numbers.

734 Figure 7: Multi-dimensional scaling plot showing the relationship between DMSP degradation 735 and UV-A light dose. The variable scores for $d m d A \mathrm{D} / 1$ transcription, phytoplankton enzyme 736 activity, and bacterial enzyme activity are also shown. Each symbol is shaded according to the

737 light UV-A dose experienced by that sample, with moderate to high light defined as a light dose 738 above $20 \%$ of the average summer surface incident UV-A $\left(0.015 \mathrm{~W} \mathrm{~m}^{-2}\right)$ and low light defined 739 as a light dose below this value.

741 Figure 8: Observed versus predicted DMS concentrations. Panel a shows observed mixed layer

742 DMS concentrations. Panel $\mathrm{b}$ shows predicted mixed layer DMS concentrations based on a 743 linear regression against potential phytoplankton DMS production, potential bacterial DMS 744 production (DLA*DMSPd), bacterial DMS consumption, and UV-A dose (which we use here as 745 a proxy for photolysis). The solid gray lines indicate the mixed layer depth and the gray circles 746 indicate sample locations. The prediction explains $42 \%$ of the observed temporal and spatial 747 variability in mixed layer DMS concentrations. February, April and November DMS values 748 could not be estimated due to missing light or rate data. 
Table 1: Correlation between DMSP degradation ( $d m d A$ transcription and enzyme activity) and observed chemical, physical, and biological parameters. For each relationship, the number of data points (n), the linear correlation coefficient (r) and $p$ value are given. Correlation coefficients with $\mathrm{p}$ values greater than 0.05 are designated non-significant $(n s)$. The percentage of elevated transcription or activity occurring under moderate to high UV-A dose is also given, where elevated transcription or enzyme activity is defined as greater than $1 \sigma$ above the mean and moderate to high UV-A dose is defined as greater than $20 \%$ of summer surface incident UV-A.

\begin{tabular}{|c|c|c|c|c|c|}
\hline & $\mathbf{n}^{a}$ & $\begin{array}{c}d m d A \mathrm{D} / 1 \\
\text { transcription }\end{array}$ & Bacterial DLA & $\begin{array}{c}\text { Bacterial DLA x } \\
\text { DMSPd }\end{array}$ & $\begin{array}{c}\text { Phytoplankton } \\
\text { DLA }\end{array}$ \\
\hline Temperature & $60(26)$ & $n s$ & $0.54(<0.01)$ & $0.44(<0.01)$ & $0.39(<0.01)$ \\
\hline Month & $60(26)$ & $n s$ & $0.48(<0.01)$ & $0.48(<0.01)$ & $n s$ \\
\hline UV-A dose & $48(22)$ & $-0.55(<0.01)^{b}$ & $n s$ & $n s$ & $0.55(<0.01)^{\mathrm{c}}$ \\
\hline DMS & $60(26)$ & $-0.56(<0.01)$ & $0.41(<0.01)$ & $0.27(0.04)$ & $0.53(<0.01)$ \\
\hline DMSPd & $60(26)$ & $0.43(0.03)$ & $0.25(0.05)$ & $0.51(<0.01)$ & $0.35(<0.01)$ \\
\hline DMSPp & $60(26)$ & $n s$ & $n s$ & $0.35(<0.01)$ & $0.33(<0.01)$ \\
\hline TOC & $59(25)$ & $-0.43(0.03)$ & $0.33(0.01)$ & $0.29(0.03)$ & $0.57(<0.01)$ \\
\hline DMSPd/TOC & $59(25)$ & $0.46(0.02)$ & $n s$ & $0.47(<0.01)$ & $0.29(0.03)$ \\
\hline DMS consumption & $54(22)$ & $-0.44(0.04)$ & $n s$ & $n s$ & $0.40(<0.01)$ \\
\hline $\begin{array}{l}\text { Bacterial Carbon } \\
\text { Demand }\end{array}$ & $60(26)$ & $n s$ & $-0.36(<0.01)$ & $-0.30(0.02)$ & $n s$ \\
\hline \multicolumn{2}{|c|}{$\begin{array}{l}\text { Amount of Elevated } \\
\text { Expression Occurring Under } \\
\text { Moderate to High UV-A }\end{array}$} & $\begin{array}{c}14 \% \\
(1 \text { of } 7)\end{array}$ & $\begin{array}{c}67 \% \\
(4 \text { of } 6)\end{array}$ & $\begin{array}{c}33 \% \\
(2 \text { of } 6)\end{array}$ & $\begin{array}{c}88 \% \\
(7 \text { of } 8)\end{array}$ \\
\hline
\end{tabular}

a Number of samples used in the correlation. The number in parenthesis is the number used for the $d m d A$ D/1 transcription correlation (column 3).

${ }^{\mathrm{b}}$ The correlation with $\ln (\mathrm{UV}-\mathrm{A})$ is $\mathrm{r}=-0.67, \mathrm{p}<0.01$

${ }^{c}$ The correlation with $\ln (\mathrm{UV}-\mathrm{A})$ is $\mathrm{r}=0.40, \mathrm{p}<0.01$ 


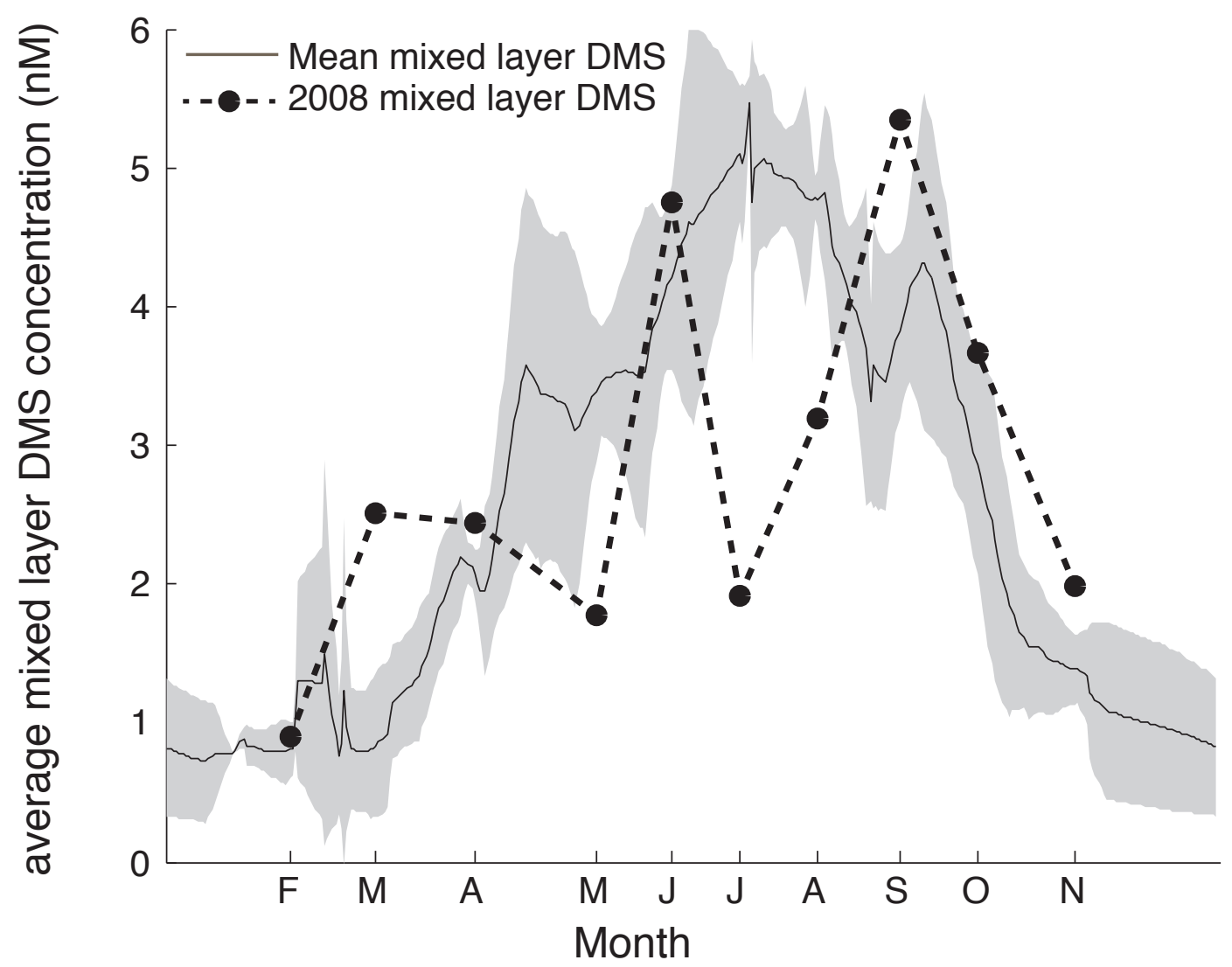



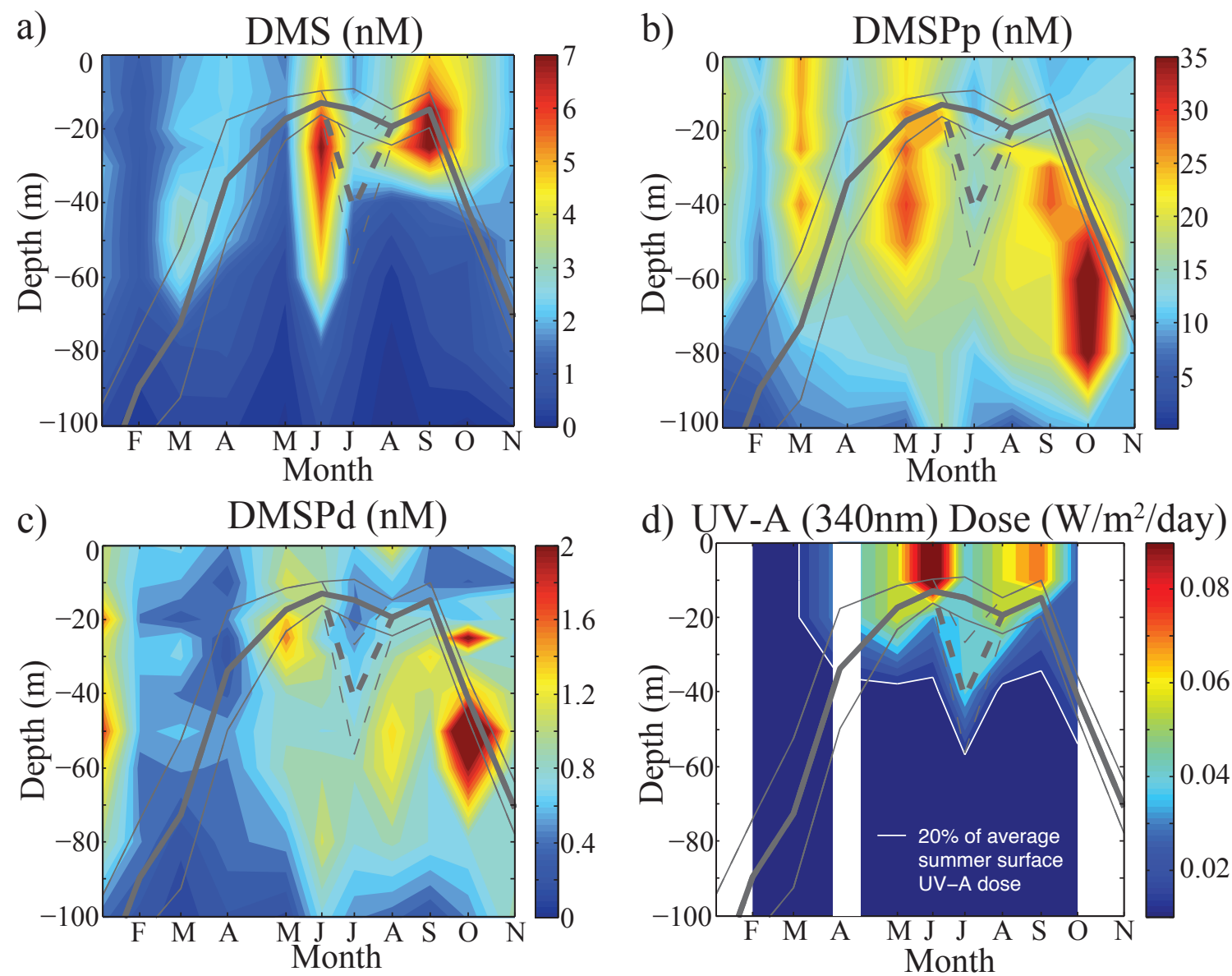

e) DMSPd Consumption (nM/day)
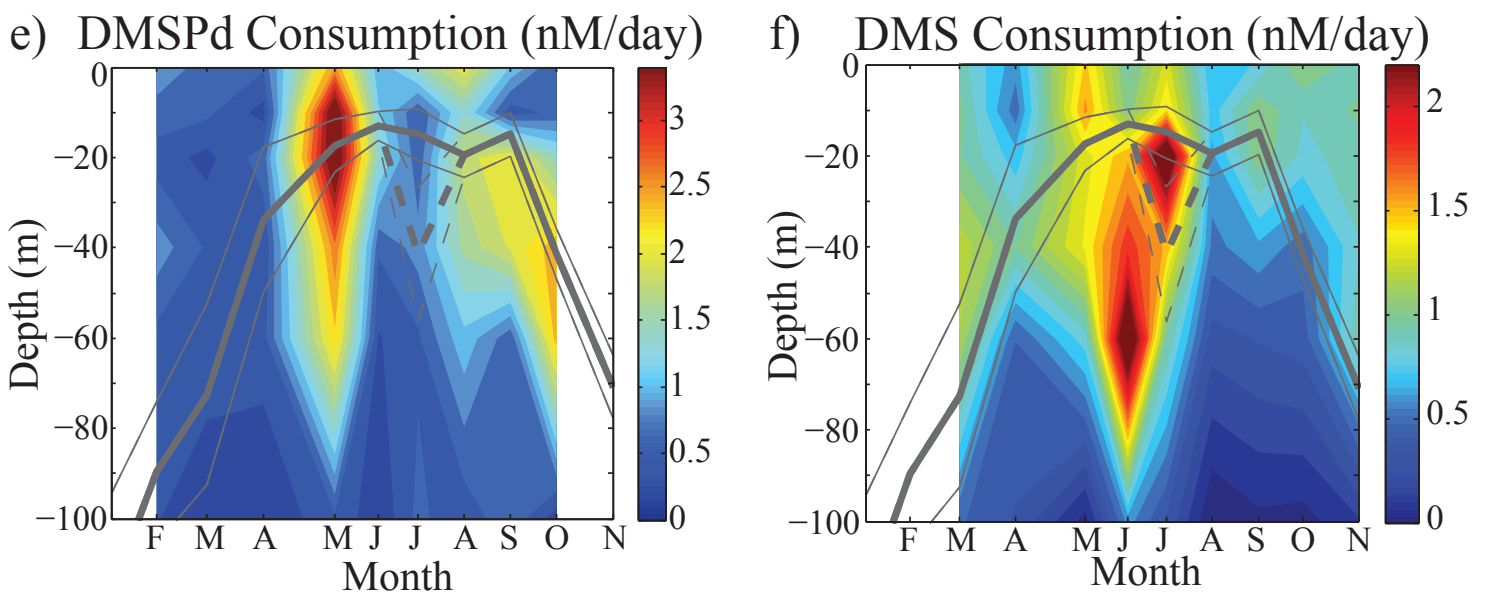

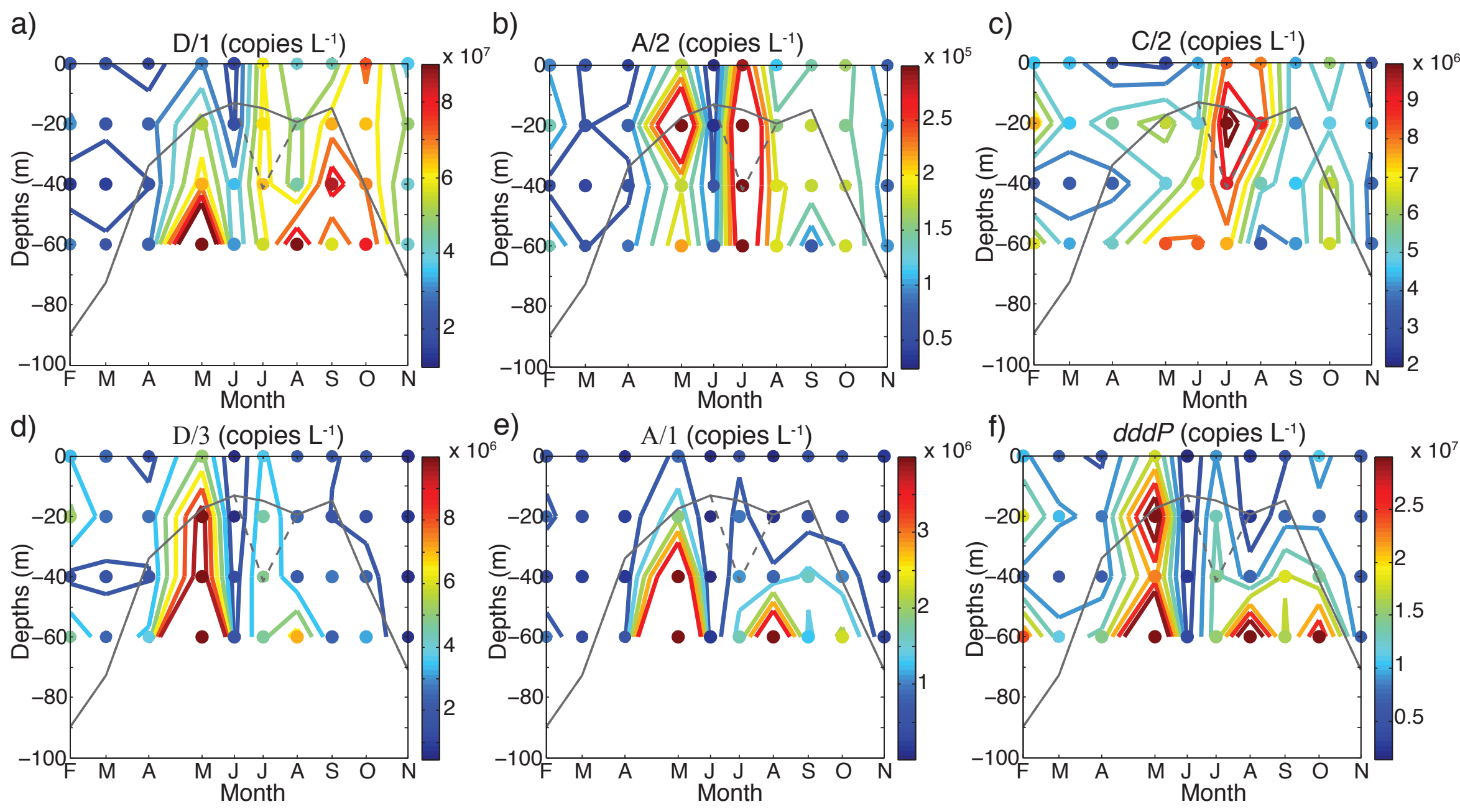

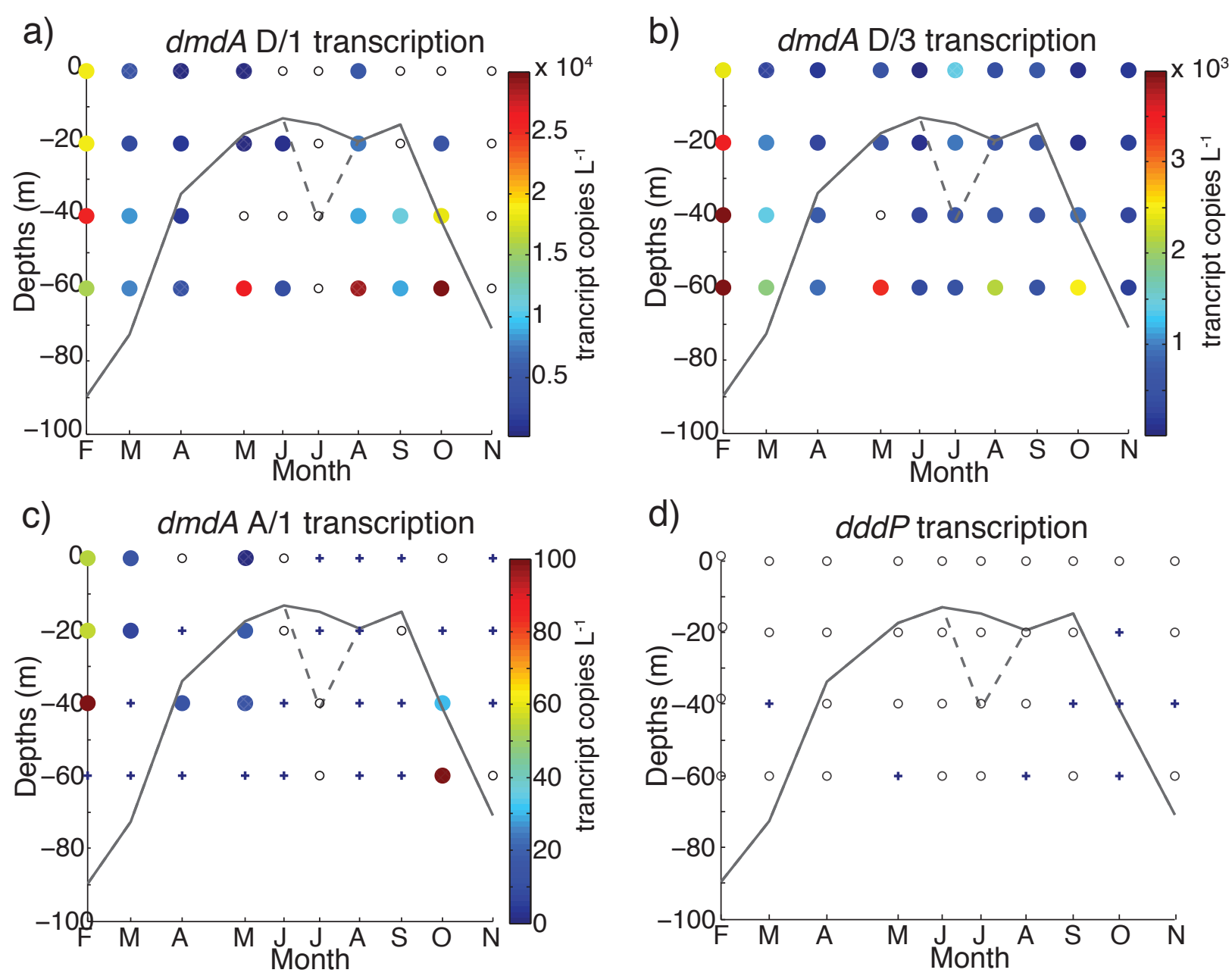
a)

Phytoplankton DMSP lyase activity

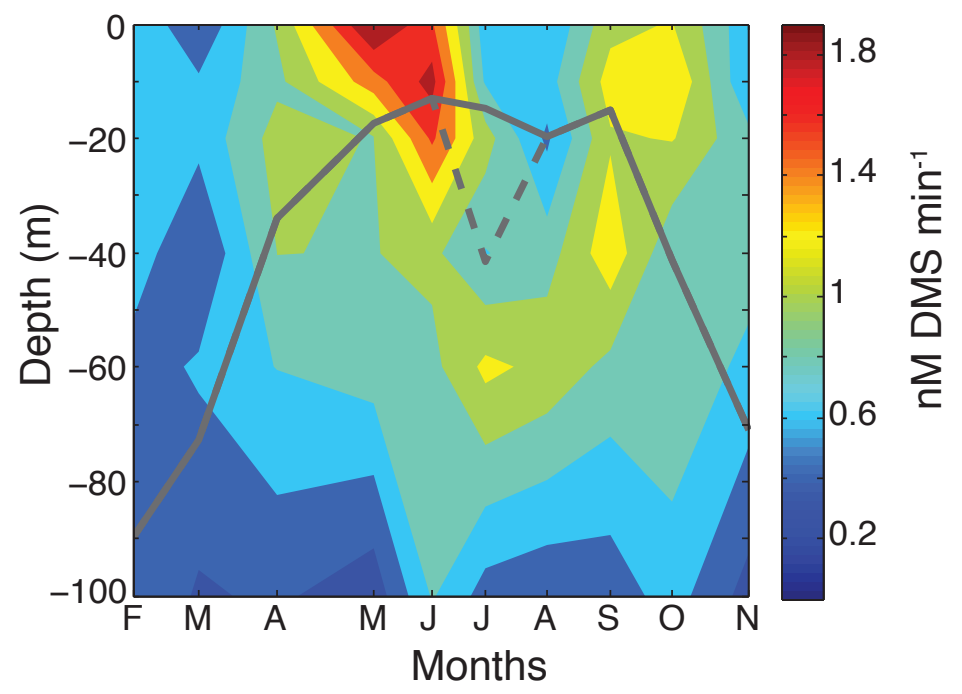

b)

Bacteria DMSP lyase activity x DMSPd

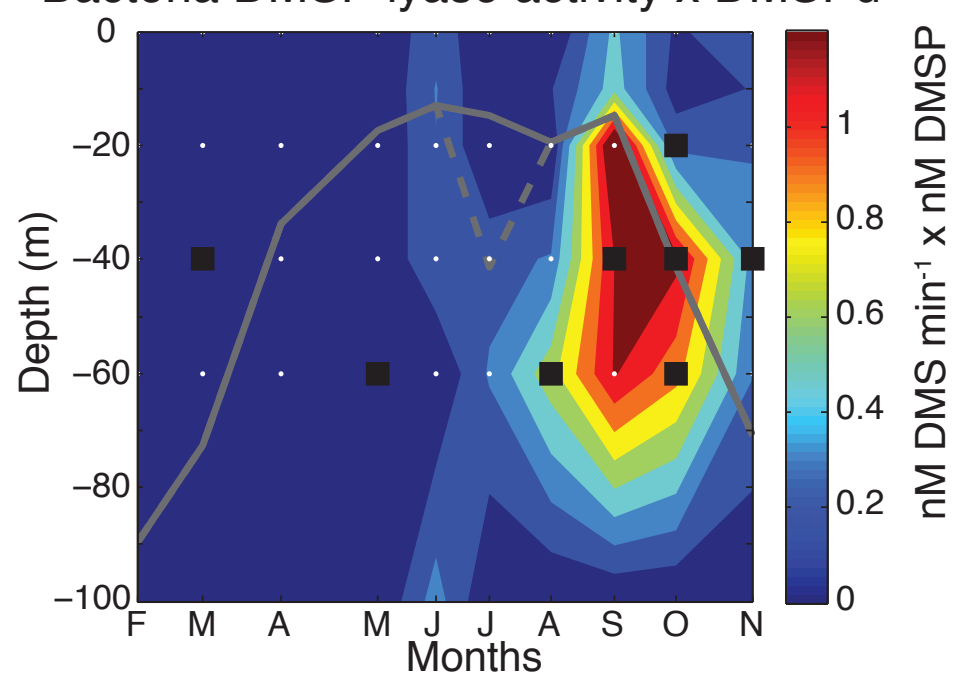




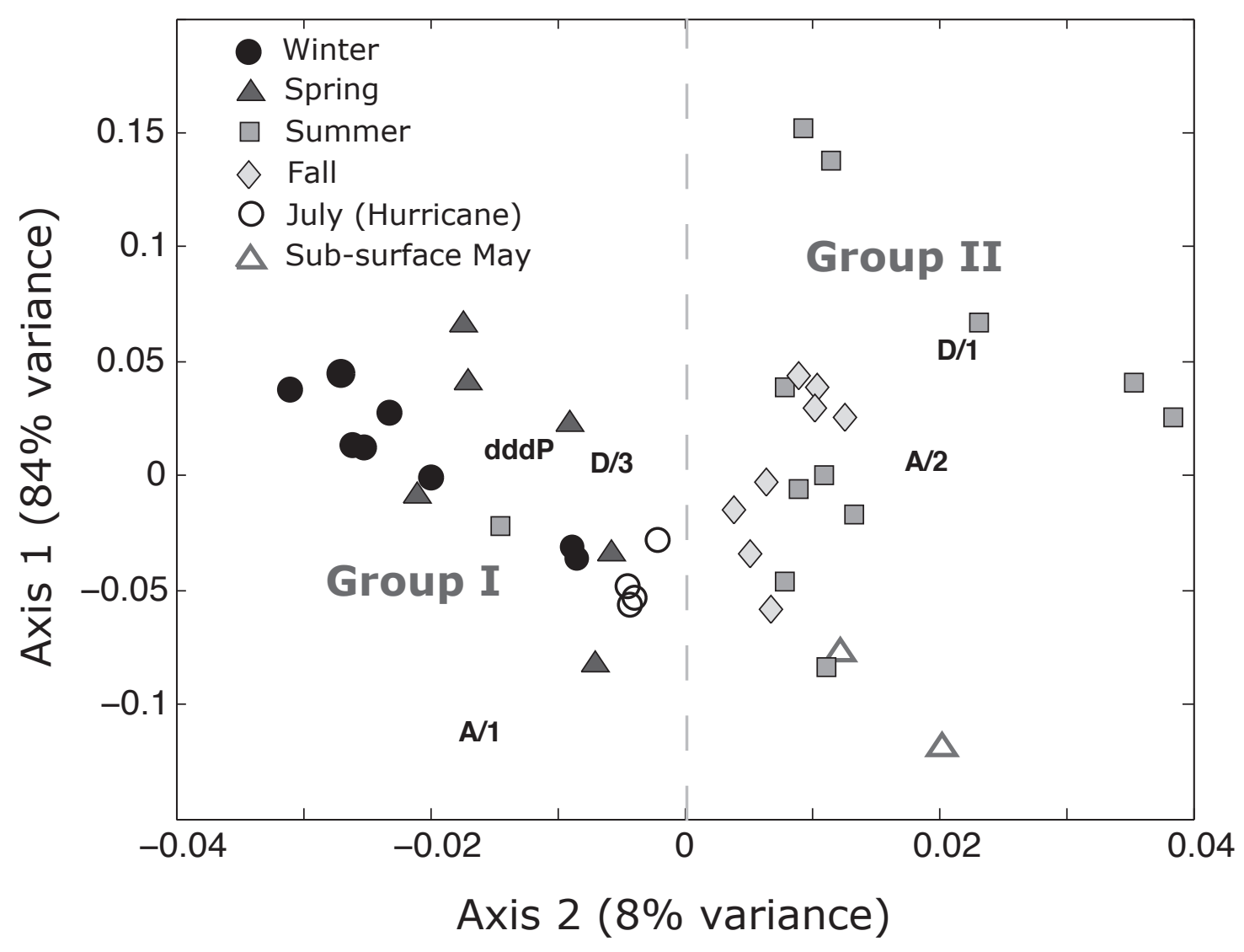




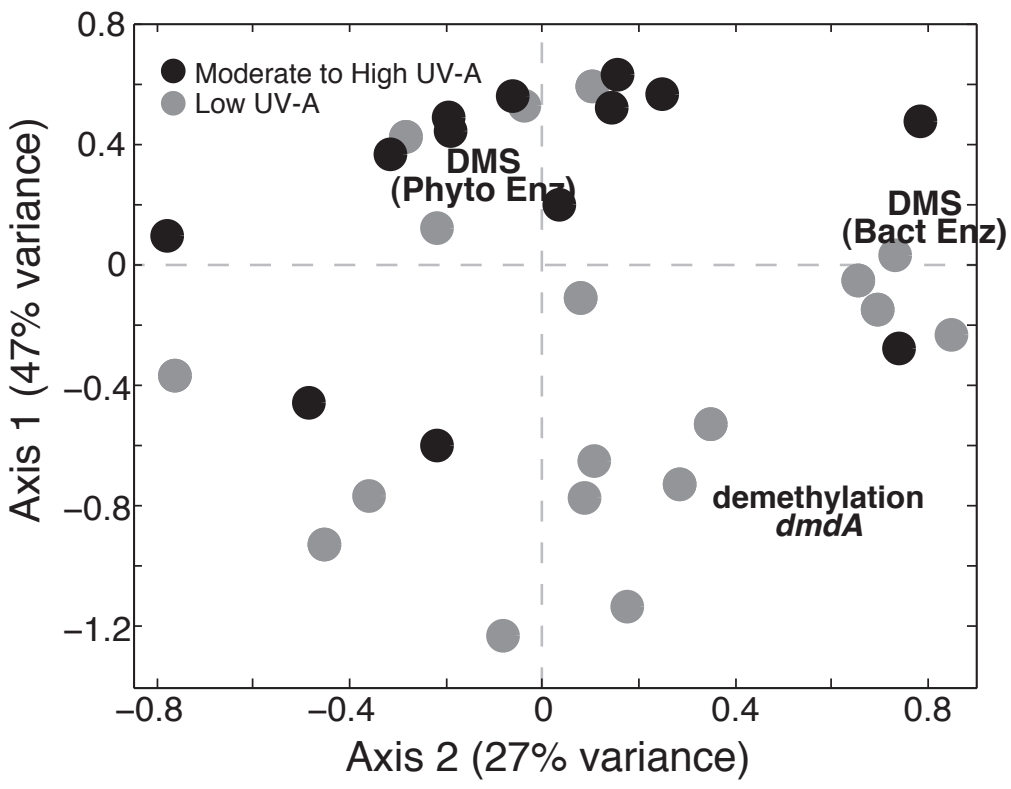


a)

Observed DMS (nM)

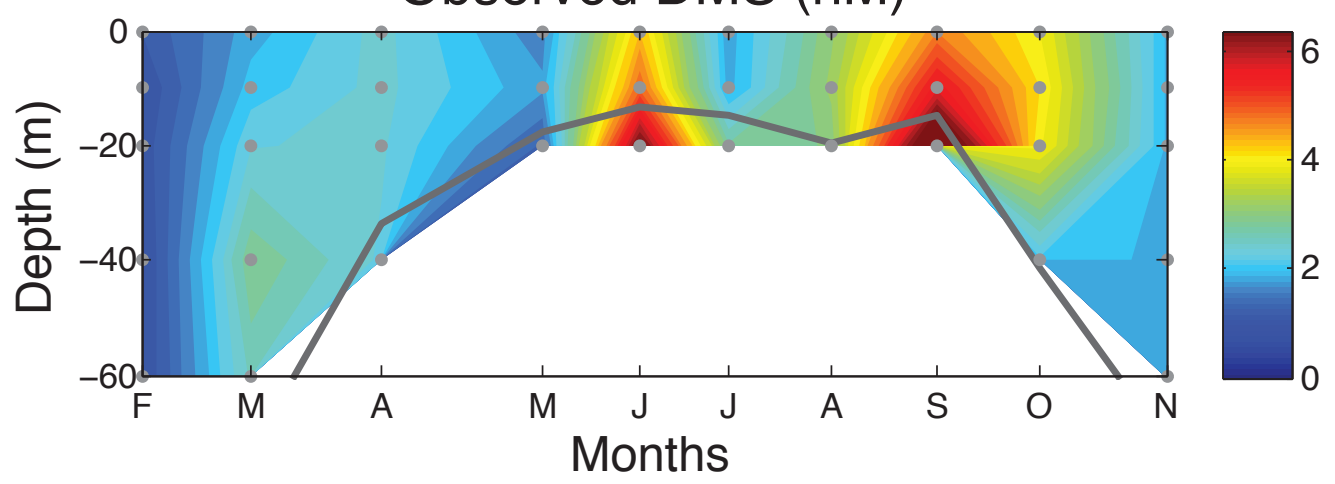

b)

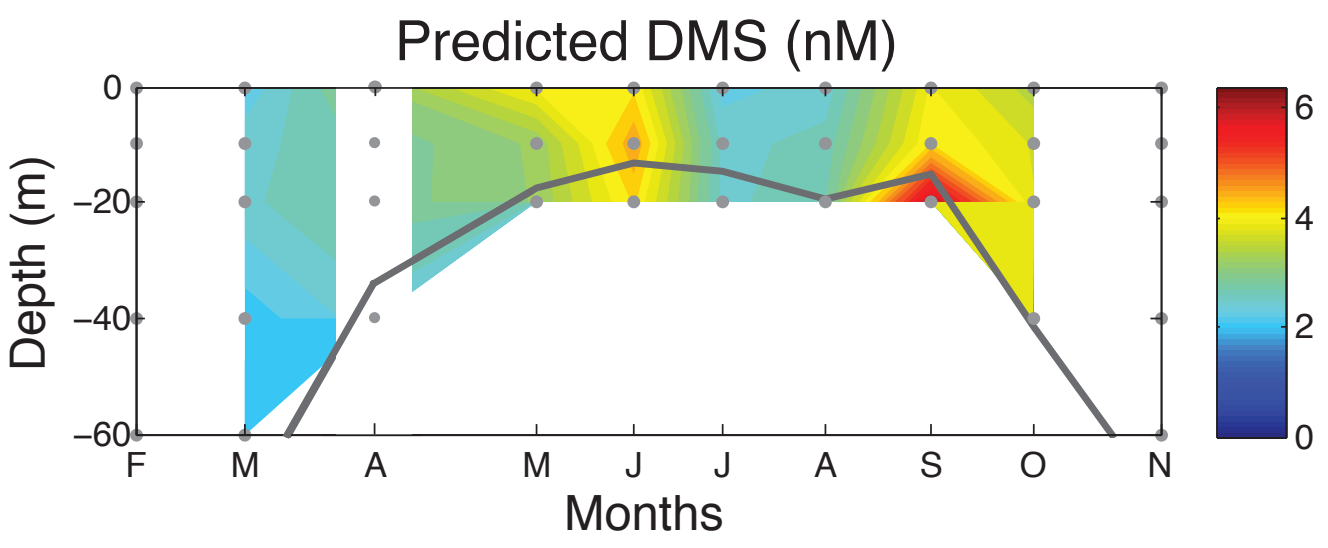

